This item was submitted to Loughborough's Research Repository by the author.

Items in Figshare are protected by copyright, with all rights reserved, unless otherwise indicated.

\title{
A systematic review on ankle injury and ankle sprain in sports
}

PLEASE CITE THE PUBLISHED VERSION

http://dx.doi.org/10.2165/00007256-200737010-00006

\section{PUBLISHER}

Springer (@ Adis Data Information)

\section{VERSION}

AM (Accepted Manuscript)

\section{PUBLISHER STATEMENT}

This work is made available according to the conditions of the Creative Commons Attribution-NonCommercialNoDerivatives 4.0 International (CC BY-NC-ND 4.0) licence. Full details of this licence are available at: https://creativecommons.org/licenses/by-nc-nd/4.0/

\section{LICENCE}

CC BY-NC-ND 4.0

\section{REPOSITORY RECORD}

Fong, Daniel Tik-Pui, Youlian Hong, Lap-Ki Chan, Patrick Shu-Hang Yung, and Kai-Ming Chan. 2019. "A Systematic Review on Ankle Injury and Ankle Sprain in Sports". figshare. https://hdl.handle.net/2134/21255. 
Title Page

Title: $\quad$ A systematic review on ankle injury and ankle sprain in sports

Authors: $\quad$ Daniel Tik-Pui FONG ${ }^{1}$, Youlian HONG ${ }^{2}$, Lap-Ki CHAN ${ }^{1}$, Patrick

Shu-Hang YUNG ${ }^{1}$, Kai-Ming CHAN $^{1}$

Institutions: $\quad{ }^{1}$ Department of Orthopaedics and Traumatology, Prince of Wales

Hospital, Faculty of Medicine, The Chinese University of Hong Kong, Hong Kong, China.

${ }^{2}$ Department of Sports Science and Physical Education, Faculty of

Education, The Chinese University of Hong Kong, Hong Kong, China.

Running title: Ankle injury and ankle sprain in sports

Acknowledgements

There are no sources of funding used to assist in the preparation of this manuscript.

There are no potential conflicts of interest the authors may have that are relevant to the contents of this manuscript.

Name and address for correspondence during review process

Name: $\quad$ Daniel Tik-Pui FONG

Address: Department of Orthopaedics and Traumatology, Faculty of Medicine, The Chinese University of Hong Kong, Hong Kong, China

Telephone: (852) 26461477 (Daniel FONG)

Facsimile: (852) 26463020 (Daniel FONG)

E-Mail: dfong@ort.cuhk.edu.hk (Daniel FONG)

Name and address for correspondence on printed articles if accepted

Name: Kai-Ming CHAN

Address: Department of Orthopaedics and Traumatology, Faculty of Medicine, The Chinese University of Hong Kong, Hong Kong, China

Telephone: (852) 26322728 (KM CHAN)

Facsimile: (852) 26377889 (KM CHAN)

E-Mail: kaimingchan@cuhk.edu.hk (KM CHAN) 
Table of Contents

Abstract

1. Introduction

2. Methods

3. Results

3.1 Demographic data

3.2 Prevalence of ankle injuries among sports

3.3 Prevalence of ankle sprains among sports

3.4 Prevalence of ankle injury and ankle sprains among countries

3.5 Incidence of ankle injuries

3.6 Incidence of ankle sprains

4. Discussion

5. Conclusion

Figure Legends

Figure 1 - Weighted percentage of ankle injury in the 70 included sports

Figure 2 - Weighted percentage of ankle sprains in the 43 included sports

Abstract

This article systematically reviewed the epidemiology studies on sports injury which ankle injury was included. The time span started from 1977 to 2005. A total of 227 studies reporting injury pattern in 70 sports from 38 countries were included. The total included cases were 201600 with 32509 (16\%) ankle injuries. A total of 11847 (84\%) ankle sprains were recorded from 14098 cases with available ankle injury information. Results show that the ankle was the most common injured body site in 24 of the 70 included sports, especially in aeroball, wall climbing, indoor volleyball, 
mountaineering, netball, and field events in track and field. Ankle sprain was the major ankle injury in 33 of the 43 sports, especially in Australian football, field hockey, handball, orienteering, scooter and squash. In general sports injury among countries, the ankle was the second most common injured body site after the knee, and ankle sprain was the most common type of ankle injury. The incidence of ankle injury and ankle sprain was high in court game and team sports, such as rugby, soccer, volleyball, handball, basketball, field hockey, dancing, American football, netball and lacrosse. This systematic review provides a summary of the ankle injury epidemiology in sports.

\section{Introduction}

People from all around the world are participating in sports nowadays for personal interest, relaxation, health and fitness training. However, sports is one of the major causes of injuries which is comparable to traffic accidents, home and leisure accidents, occupational injuries, and violence ${ }^{[1-4]}$. Sports injuries result in pain, loss of playing or working time, as well as medical expenditure. Severe injuries may result in bone fractures, functional instability, limited mobility, disability, permanent cease of sports participation, psychological problem, and perhaps death. For world-class and commercial sports teams, absence of key players due to unexpected injuries may result in defeats in major games and huge economic loss. Due to these undesired adverse effects, scientists and medical specialists are actively working on sports injury prevention $^{[5-7]}$. The aim is to prevent sports injury and let people enjoy sports participation.

The first procedure to tackle a problem is to identify the problem. In 1970, Roser and Clawson conducted an epidemiology study on football injuries in young athlete ${ }^{[8]}$. In 
1971, MacIntosh conducted similar study on athletic injuries in University of Toronto $^{[9]}$. In 1972 and 1973, Garrick conducted related studies in prevention of sports injuries $^{[5]}$ and prevention of ankle sprains ${ }^{[10]}$. To be more specific in identifying the problem, Garrick pioneered a series of ankle sprains epidemiology studies from $1977^{[11]}$. Subsequent studies by Garrick investigated ankle injuries in different sport events including aerobic dance ${ }^{[12]}$, children and adolescent skiing ${ }^{[13]}$, women gymnastics $^{[14]}$, ballet ${ }^{[15]}$, and in all sports ${ }^{[16]}$. From 1980 afterwards, numerous epidemiology studies were conducted on different sports, population, gender, playing level and in different countries ${ }^{[3,16-21]}$. These epidemiology studies generally reported that ankle is one of the most traumatized body sites in sports injuries in an overview on different sports, population, gender, playing level and in different countries. They reported that ankle injuries are accounting for $10-30 \%$ of all sports injuries. In some sports, the percentage of ankle injuries is even higher, such as $40 \%$ in mountaineering $^{[22]}$ and handball ${ }^{[23]}, 41 \%$ in volleyball ${ }^{[24]}$ and youth soccer $^{[25]}, 45 \%$ in female cheerleading ${ }^{[26]}, 46 \%$ in artistic gymnastic ${ }^{[27]}, 53 \%{ }^{[28]}$ and $54 \%^{[29]}$ in softball, and $56 \%$ in women floorball ${ }^{[30]}$. In 1988 , Garrick reported that the percentage can be higher in some sports ${ }^{[16]}$. From epidemiology data collected from 1979 to 1987, that percentage of ankle injuries was $74 \%$ in softball, $76 \%$ in racquet sports and football, $77 \%$ in weight-lifting and dancing, $79 \%$ in basketball, and $82 \%$ in volleyball. Ankle sprain is the most common type of ankle injury in most sports. It may account for more than $80 \%$ and even as much as $100 \%$ of ankle injury sustained in some sports, such as squash ${ }^{[31]}$, orienteering ${ }^{[32]}$, scooter ${ }^{[33]}$ soccer $^{[34]}$, figure skating ${ }^{[35]}$, Australian football $^{[36]}$, rugby $^{[37]}$, field hockey ${ }^{[38]}$, handball ${ }^{[39]}$ and volleyball ${ }^{[24]}$. In those sprains, about $77 \%$ of them are lateral sprains ${ }^{[40]}$ and $73 \%$ of them involved rupture or tear to anterior talofibular ligament ${ }^{[41]}$. In a survey conducted in 1994 on 380 athletes with 563 sprained ankles, Yeung reported that most of these injured athletes were pursuing 
running and jogging activities (25\%), racquet sports (20\%), ball games (19\%), soccer (14\%) and fencing (6\%) ${ }^{[21]}$. The residual problem included pain (30.2\%), instability (20.4\%), crepitus (18.3\%), weakness (16.5\%), stiffness (14.6\%) and swelling (13.9\%). For ankle sprained once to four times, the major residual problem is pain (24-28\%). For ankle sprained five times or more, instability problem arises and becomes the major sequale (38\%).

In 1987, van Mechelen proposed a "sequence of injury prevention" which describes how sport injuries related studies stand together and form the whole research framework $^{[42]}$. The first step is to identify the extent of the sports injury problem by epidemiology studies. The second step is to establish the aetiology and mechanism of injuries. The third step is to design and introduce preventive measures. Finally the effectiveness of the preventive measures is assessed by repeating the first step, which is the epidemiology study. Those epidemiology studies conducted by Garrick and other researchers ${ }^{[11-16]}$ play an important role in locating the problem of ankle sprains in sports in the model of "sequence of injury prevention". With this information, subsequent studies can be done to identify risk factors to injury ${ }^{[43]}$ and injury mechanism $^{[44]}$, to design prevention equipment ${ }^{[45,46]}$, and to finally evaluate the effectiveness of these preventive measures ${ }^{[47,48]}$. The purpose of this study is to systematically review the epidemiology studies on sports injury published by researchers in different sports and countries from 1977 to 2005 in order to identify the distribution of reported injuries among ankle and other body sites. Moreover the ankle injury types were also summarized. The time span starts from the first epidemiology study on ankle sprains published by Garrick in $1977^{[11]}$. The summarized findings will help sports medicine specialists to identify the patterns of ankle injury in sports, and to reassure the targets of future researches. 


\section{Methods}

Systematic literature search of Medline (from 1966), ISI Web of Knowledge (Science Citation Index Expanded, from 1985; Social Sciences Citation Index, from 1956; Arts \& Humanities Citation Index, from 1975), PubMed (from 1950), and Sport Discus (from 1975) was conducted at the last week of January in year 2006. The search keyword string was "ankle AND (injury OR injuries OR sprain) AND (sport OR sports) AND (epidemiology OR epidemiologic OR epidemiological OR survey OR statistics OR patterns OR pattern)” appeared in title, abstract and keyword fields. The initial total number of identified articles from these databases was 744. After removing duplicates the count was reduced to 514. The title and abstract of each entry was read to identify and exclude non-epidemiology and non-related studies. Articles not written in English were excluded. After the trimming the count was reduced to 419. Online and library search for full text of these 419 articles was conducted. Articles not available in the library in The Chinese University of Hong Kong were requested from other libraries in local universities. The number of the article which full text was retrieved was 331.

The full text of each of the 331 retrieved articles was read in order to determine inclusion or exclusion in the analysis. To be included in the analysis, the study should report epidemiology findings of injury sustained in one or more sports activities, and should fulfill either one of the two following criteria: (1) the study reported injury at ankle joint, with either prevalence percentage among other body sites, or the incidence rate among the surveyed sample, (2) the study reported ankle sprain injury, with either prevalence percentage among other ankle injury types, or the incidence rate among the surveyed sample. Review articles, case report and current concepts 
from specialists were excluded. After the screening process the final number of articles included in the analysis was 227.

Demographic data of the included studies were summarized. It included the geographical location where the study was conducted, period of the study, population investigated, prospective or retrospective nature of the study and case number. Geographical location was summarized in country and continent where the study was conducted. Period of study was categorized as before 1980, 1981-85, 1986-90, 1991-95, 1996-00 and 2001-05. Population investigated was categorized as (1) team, which the subjects were from sport teams or clubs, (2) public, which the subjects were from public population attending accident and emergency department in hospitals or sports medicine clinics, (3) event, which the subjects were from competition events and games, (4) school, which the subjects were student athletes from schools and universities, and (5) military, which the subjects were military recruits. Case number was categorized in 5-year intervals as 1-100, 101-500, 501-1000, 1001-2000, 2001-5000, 5001-10000 and $>10000$. Some studies reported data in a period of time overlapping two or more 5-year intervals were counted in all period included and made the total counts exceeding the total number of study.

The 227 included studies reported a total of 255 epidemiology reports, as some studies reported epidemiology in more than one sport. All epidemiology reports were categorized in sports. Epidemiology studies reporting general sport injury patterns in a country but not on specific sport were categorized in countries.

In each sport and country, the most common injured body sites and ankle injury types ranked by weighted prevalence percentages were shown in tables. Eleven body site 
group were categorized: (1) ankle, (2) foot, (3) leg / shin / calf, (4) knee, (5) thigh / hamstring, (6) hip, (7) trunk / back / spine, (8) shoulder, (9) arm / elbow, (10) hand / fingers, and (11) head / neck / face. Some studies reported the percentage of injury of several body sites, such as foot and ankle, hip and thigh, or arm and shoulder. For these studies the combined percentages were divided evenly for each included site. Some studies combined the whole upper or lower extremity and made the distribution pattern among each body site too superficial. In these cases the study will be excluded as it failed to comply with the inclusive criteria that the study should report injury pattern in different body sites with ankle injury reported. However if ankle and hand injury were separately reported from lower and upper extremities, the study was included and the percentages of lower and upper extremity were considered in the leg (leg / shin / calf) and arm (arm / elbow) categories. Ankle injury type was classified into 11 categories: (1) sprain, (2) fracture, (3) strain, (4) abrasion, (5) contusion, (6) tendinitis, (7) blister, (8) impingement, (9) cramp, (10) bruise, and (11) laceration.

Among injured body sites, prevalence of ankle injury was represented by weighted percentages calculated by the sum of the percentage of injury in a specific body site times the number of all injuries in each included study, then divided by the sum of the total number of all injuries. Among ankle injury types, prevalence of ankle sprain was represented by weighted percentages calculated by the sum of the percentage of ankle injury type times the number of all ankle injuries in each included study, then divided by the sum of the total number of all ankle injuries. The calculations were shown in the following mathematics formula. 
weighted percentage $($ body site $)=\frac{\sum_{i=1}^{n} \text { total case } \times \text { percentage }(\text { body site })}{\sum_{i=1}^{n} \text { total case }}$

weighted percentage (ankle injury type $)=\frac{\sum_{i=1}^{n} \text { total ankle injuries } \times \text { percentage (ankle injury type) }}{\sum_{i=1}^{n} \text { total ankle injuries }}$

where $n=$ number of epidemiology reports in one specific sport or country

In addition, incidence rate of ankle injuries and ankle sprain were reported in incidence per 1000 person-hours / person-year / person-season / person-exposure.

\section{Results}

\subsection{Demographic data}

Two-hundred-twenty-seven epidemiology studies were included. Some studies reported injury epidemiology in two or more countries and thus made the total count 255. Most studies were conducted in Europe (45.5\%), North America (30.2\%) and Australasia (11.8\%). Only a few studies were from Asia (4.3\%), South America (2.0\%) and Africa (0.4\%). Distribution of geographical location of the included studies is shown in Table 1. Among countries, results showed that most studies were conducted in the United States (24.3\%), followed by the United Kingdom (13.3\%), Australia (8.2\%), Sweden (7.1\%) and Denmark (6.3\%).

The period of study, population investigated, nature of study and the case number were summarized in Table 2. Most epidemiology studies were published from 1986-2000 with even distribution among this time span. Thirty-seven studies (12.9\%) did not report the duration of study. The population investigated was mostly from sports team and clubs (40.5\%), followed by public participants (29.5\%), competition 
event (15.4\%), schools (11.0\%), and military (0.9\%). Six studies (2.6\%) did not describe the population investigated. Nature of study was identified to be prospective (75.3\%) or retrospective (18.9\%). Thirteen studies (5.7\%) did not describe the study nature. Most studies had case volume from 101-500 (49.8\%). The total case number of sports injury included was 201600, and the number of ankle injuries included was 32509.

\subsection{Prevalence of ankle injuries among sports}

The total number of sports included in the analysis is 70. The weighted percentage of the most common injured body sites were shown in Table 3. Among these 70 sports, ankle ranked first in the most popular injured body site in most studies (24 sports, 34.3\%), followed by knee (14 sports, 20.0\%), head (8 sports, 11.4\%), trunk (6 sports, 8.6\%) and hand (6 sports, 8.6\%). Figure 1 showed the weighted percentage of ankle injury in all 70 included sports. Ankle injury was most common in aeroball (80.0\%), wall climbing (60.0\%), indoor volleyball (45.6\%), mountaineering (40.0\%), netball (39.8\%) and field events in track and field (39.2\%). The prevalence of ankle injuries was over $20 \%$ in 25 sports.

\subsection{Prevalence of ankle sprains among sports}

Information about ankle injury was available in 43 sports, as shown in Table 4 . The total case number of sports ankle injury included in analyzing the ankle injury type was 14098 , and the number of ankle sprains was 11847. Ankle sprain was most common (33 sports, 76.7\%), followed by fracture (7 sports, 16.3\%). Figure 2 showed the weight percentage of ankle sprain in the 43 included sports. In some sports, all reported ankle injuries were ankle sprain (100\%). These sports included Australian football, field hockey, handball, orienteering, scooter and squash. In addition to these 
six sports, ankle sprain percentage was also higher than $80 \%$ in indoor volleyball, American football, martial arts, basketball, aeroball, ultimate, flag football, cheerleading, indoor soccer, ice hockey, lacrosse, badminton and netball.

\subsection{Prevalence of ankle injury and ankle sprains among countries}

Epidemiology data in general sports were available in eight countries as shown in Table 5. In general, the knee was the most popular injured site (16.0-27.0\%), followed by the ankle (11.2-20.8\%), with an exception that the hand was most popular in Sweden (19.8\%) and Holland (21.8\%). For Holland, ankle ranked second (20.8\%) after the hand (21.8\%). For Sweden, ankle ranked third (15.6\%) after the hand (19.8\%) and the knee (16.0\%) Ankle injury type information was available in three countries. Sprain was the most popular type of ankle injuries (33.0-73.0\%), followed by abrasion (25.2\%) and fracture (7.4-16.0\%).

\subsection{Incidence of ankle injuries}

Incidences of ankle injuries were shown in Table 6. In terms of incidence per 1000 person-hours, hurling and camogie had the highest general incidence (32.88), followed by rugby (8.14), soccer (6.52), basketball (5.20) and triathlon (4.70). In game, the incidence was highest in soccer (34.83), followed by rugby (14.00), American football (13.80) and indoor soccer (11.68). In training, soccer showed the highest incidence rate (2.74). In terms of incidence per 1000 person-year, field hockey showed the highest incidence rate (1000.00), followed by orienteering (571.43), dancing (466.20), gymnastics (425.90) and gaelic football (374.70). In terms of incidence per 1000 person-season, soccer showed the highest incidence in general (1200.00), game (143.40) and training (64.00). Australian football also has comparable game incidence (111.10). In terms of incidence per 1000 person-exposure, 
tennis showed the highest incidence (11.30), followed by basketball (9.17) and netball (5.26). In game, netball showed the highest incidence (45.60), followed by rugby (8.88), American football (6.38), basketball (3.77) and wrestling (2.71).

\subsection{Incidence of ankle sprains}

Incidences of ankle sprains were shown in Table 7. In terms of incidence per 1000 person-hours, rugby had the highest general incidence (4.20), followed by soccer (2.52), volleyball (1.99), handball (1.59) and basketball (1.00). In game, the incidence was highest in soccer (11.68), followed by Australian football (4.86) and soccer (4.59). In terms of incidence per 1000 person-year, field hockey showed the highest incidence rate (1000.00), followed by rugby (233.40), basketball (173.50), dance (155.40) and American football (60.60). In terms of incidence per 1000 person-season, soccer showed the highest incidence in general (1200.00), while Australian football showed the highest incidence in game (111.10). In terms of incidence per 1000 person-exposure, lacrosse showed the highest incidence (2.56), followed by basketball (1.90), Alpine skiing (1.60), soccer (1.15) and field hockey (0.90). In game, netball showed the highest incidence (40.06), followed by rugby (6.31), American football (6.06) and basketball (3.45).

\section{Discussion}

This is a large scale systematic review which involved 227 published studies from 38 countries, reporting injury pattern in 70 different sports with a total of 201600 included injury cases and 32509 included ankle injury cases. A total of 14098 ankle injuries were included in analyzing the most common ankle injury type, and 11847 ankle sprains were included in this study. The time span covered the past 29 years from 1977 to 2005 inclusive. With such large coverage on the published data 
contributed from researchers all around the world, this literature research should attract attention from researchers in identifying the problem of sports injury in injury prevention research. Although the details of injury in each sport cannot be listed out in this paper, researchers may learn the overview of published epidemiology data and identify the relevant articles for further information from this review. However, readers should pay attention that only those epidemiology studies with ankle injury reported were included in this analysis. This study can be a deputy in only ankle injury patterns in sports but not in general injury patterns.

Most epidemiology studies included in this analysis were from English speaking countries in North America, Europe and Australasia. There were fewer studies from Asia, South America and Africa. However, literature search showed epidemiology studies published from these countries in their own language. However as a result of language barrier, these studies are not included. Moreover, due to higher education level, scientific research activities were more active in those developed countries in North America, Europe and Australasia. Therefore most of the included studies were contributed by these countries and made the analysis more representing the injury pattern in these countries rather than a global fact. This is a limitation from the language and level of scientific research activities.

Some studies, especially those published in older years, did not describe full demographic details of the study. The information was obvious but the authors sometimes just did not report them. For example, some authors did not report the location which the study was conducted ${ }^{[11,12,15,49-57]}$. Some may only report the city or town name and it was sometimes impossible for international reader to identify its exact location ${ }^{[16,58,59]}$. The nature of study, the period of data collection, and the 
participants investigated were also often missed, as indicated in Table 2. Although these data might not be always important to every reader, reporting this information enriches the completeness of the published epidemiology study.

From the period of study reported, there were not many published epidemiology studies reporting sports with ankle injury before 1980. After 1981, the number of these studies increased and remained in a steady amount of published studies until 2000. From 2001 to 2005 the number of recorded studies dropped. This may reflect a decline of interest of epidemiology researches, a shift in sport event of interest which involves no ankle injury, or maybe a total vanish of ankle injury in some sports in recent years. The populations investigated were mainly team athletes (40.5\%) and public participants (29.5\%), which should well represent organized and recreational sports participation. Three fourth $(75.3 \%)$ of the studies were prospective, which are expected to better represent the real injury patterns from better experimental control and data collection procedure. Most studies (49.8\%) were with included cases from 101-500, which was quite enough for epidemiology data reporting. Therefore the authors believed that the summarized findings are representative and should have significant value in helping readers to identify the ankle injury patterns.

Within the 70 included sports, ankle injury was most common in 24 sports, with highest weighted percentage in aeroball (80.0\%), wall climbing (60.0\%), indoor volleyball (45.6\%), mountaineering (40.0\%), netball (39.8\%) and field events in track and field (39.2\%). Within the 43 sports with information about ankle injury, ankle sprain was most common in 33 sports. The percentage of sprain among all ankle injuries reached $100 \%$ in 6 sports, over $80 \%$ in 19 sports, over $60 \%$ in 26 sports, and over $40 \%$ in 34 sports. Among the eight countries included in this study, the knee was 
the most popular injured site (16.0-27.0\%), followed by the ankle (11.2-20.8\%), with an exception that the hand was most popular in Sweden (19.8\%) and Holland (21.8\%). Sprain was the most popular type of ankle injuries (33.0-73.0\%) from the information from three included countries. From the results, ankle injury was concluded to be one of the most commonly injured body sites in sports, and ankle sprain was the most dominating type of ankle injury in most of the sports.

In studying the weighted percentage of the injured body sites, reader should note that the higher percentage did not necessarily mean higher incidence of injury to this site. The figures only represented the distribution of the recorded injury in different sites. For example a $80.0 \%$ ankle injury rate in aeroball did not mean a more frequent injury occurrence to a $21.2 \%$ ankle injury rate in soccer, as the incidence rate of injury in soccer (71.13 incidence per 1000 person-year) was much higher than that in aeroball (1.37 incidence per 1000 person-year). From this review, the incidence of ankle injury and ankle sprain were high in court game and team sports, such as rugby, soccer, volleyball, handball, basketball, American football, Australian football, Gaelic football, tennis, netball, lacrosse and field hockey. Moreover, the incidence was also high in gymnastics, orienteering, dancing and skiing. In general, incidence in competitive games was higher than in general.

Moreover, reader should be aware that a higher incidence rate did not necessarily mean higher severity of the sports injury. It only reported the frequency of injury occurrence but did not report the severity of each injury. In ankle sprain, the severity can be ranked in grades, such as Grade 1, 2 and 3. However there were several kinds of rating scale for ankle sprain. Moreover, such information was rarely reported in the epidemiology studies and thus was not summarized in this review study. 
The high incidence did not yet show the whole fact of the sports injury. For example, among the listed sports with high ankle injury and ankle sprain incidence, soccer may have the highest ankle sprain case amount as it was a very popular sport in the world. Although lacrosse showed a higher ankle sprain incidence (2.56 incidence per 1000 player-exposure) than soccer did (1.15 incidence per 1000 player-exposure), the total case amount of ankle sprain sustained in lacrosse sport may be fewer as the sport was less popular. Such information of total amount of incidence was not available from this review. Garrick and Requa ${ }^{[16]}$ conducted a prospective epidemiology studies in the United States from 1979 to 1987 with 19 sports with 17750 included cases. Among these cases, most of them were sustained during running (about 4200, 24\%). The total number of ankle injuries were highest in running (about 350), followed by ballet (about 220), basketball (about 130), tennis (about 90) and soccer (about 70). Although the percentages of ankle injuries were higher in soccer and basketball in Garrick and Reque’s study ${ }^{[16]}$, the total case number was fewer than that of running as a result of smaller participation rate. From the results from this study, the incidence rate per 1000 player-hours was 0.02 for running, 5.20 for basketball and 6.52 for soccer. This showed that with we should also consider the popularity of a specific sport, or the total participants in this specific sport, in order to decide which sport we should select to implement injury prevention measures.

The results from this study may give sports medicine specialist some idea to decide their target sports for implementing injury prevention protocols to prevent ankle sprain. It also can serve as a standard or baseline for sports team to evaluate their injury pattern by comparing it to the reported data in this review. If a team or league recorded higher ankle injury or ankle sprain incidence than those found in the 
literature, it may be necessary to closely examine the injuries, sports equipment, facilities and everything. Moreover, when injury prevention protocols were introduced to a certain population, sports medicine specialists can evaluate their effectiveness by investigating the injury patterns and incidence with the data reported in this study.

\section{Conclusion}

Ankle injury was most common in aeroball, wall climbing, indoor volleyball, mountaineering, netball, and field event in track and field. Among ankle injury, ankle sprain was the most common injury type. In Australian football, field hockey, handball, orienteering, scooter and squash, all of the reported ankle injuries were sprain. Sprain was also very common in other sports, especially the court and team sports. In epidemiology of sports injury from general sports among countries, the knee was the most suffering body sites, preceding the ankle. In the United States, Holland and Hong Kong, ankle sprain was the most common ankle injury type. Ankle injury and ankle sprain incidences were highest in court game and team sports, such as rugby, soccer, volleyball, handball and basketball.

This systematic review provides a summary of the ankle injury epidemiology in sports. It helps sports medicine specialist in deciding which sport to implement injury prevention measures. However, one should also pay attention on the popularity of sports as a high participate rate would also significant increase the total injury cases. We suggested that ankle sprain prevention should be implemented in rugby, soccer, volleyball, handball and basketball. We should also implement ankle sprain prevention in running, as it is the most popular sport in the world with most participants. 


\section{Address for correspondence:}

Prof Kai-Ming Chan, Department of Orthopaedics and Traumatology, Prince of Wales Hospital, Faculty of Medicine, The Chinese University of Hong Kong, Shatin, Hong Kong, China. Email: kaimingchan@cuhk.edu.hk

\section{References}

1. de Loes M, Goldie I. Incidence rate of injuries during sport activity and physical exercise in a rural Swedish municipality: incidence rates in 17 sports. International Journal of Sports Medicine 1988; 9 (6): 461-7

2. Dekker R, Kingma J, Groothoff JW, et al. Measurement of severity of sports injuries: an epidemiological study. Clinical Rehabilitation 2000; 14 (6): 651-656

3. Holmer P, Sondergaard L, Konradsen L, et al. Epidemiology of sprains in the lateral ankle and foot. Foot and Ankle International 1994; 15 (2): $72-74$

4. Michaud PA, Renaud A, Narring F. Sports activities related to injuries? A survey among 9-19 year olds in Switzerland. Injury Prevention 2001; 7 (1): 41-45

5. Garrick JG. Prevention of sports injuries. Postgraduate Medicine 1972; 51 (1): $125-9$

6. Parkkari J, Kujala UM, Kannus P. Is it possible to prevent sports injuries? Review of controlled clinical trials and recommendations for future work. Sports Medicine 2001; 31 (14): 985-995

7. Thacker SB, Stroup DF, Branche CM, et al. The prevention of ankle sprains in sports: a systematic review of the literature. American Journal of Sports Medicine 1999; 27 (6): 753-760

8. Roser LA, Clawson DK. Football injuries in the very young athlete. Clinical Orthopaedics and Related Research 1970; 69: 219-23

9. MacIntosh DL, Skrien T, Shephard RJ. Athletic injuries at the University of Toronto. Medicine and Science in Sports 1971; 3 (4): 195-9

10. Garrick JG, Requa RK. Role of external support in the prevention of ankle sprains. Medicine and Science in Sports 1973; 5 (3): 200-3

11. Garrick JG. The frequency of injury, mechanism of injury, and epidemiology of ankle sprains. American Journal of Sports Medicine 1977; 5 (6): 241-242

12. Garrick JG, Gillien DM, Whiteside P. The epidemiology of aerobic dance injuries. American Journal of Sports Medicine 1986; 14 (1): 67-72

13. Garrick JG, Requa RK. Injury patterns in children and adolescent skiers. American Journal of Sports Medicine 1979; 7 (4): 245-248 
14. Garrick JG, Requa RK. Epidemiology of women's gymnastics injuries. American Journal of Sports Medicine 1980; 8 (4): 261-264

15. Garrick JG, Requa RK. Ballet injuries. An analysis of epidemiology and financial outcome. American Journal of Sports Medicine 1993; 21 (4): 586-90

16. Garrick JG, Requa RK. The epidemiology of foot and ankle injuries in sports. Clinics in Sports Medicine 1988; 7 (1): 29-36

17. Barker HB, Beynnon BD, Renstrom PA. Ankle injury risk factors in sports. Sports Medicine 1997; 23 (2): 69-74

18. Beynnon BD, Renstrom PA, Alosa DM, et al. Ankle ligament injury risk factors: a prospective study of college athletes. Journal of Orthopaedic Research 2001; 19 (2): 213-20

19. de Bie RA, de Vet HC, van den Wildenberg FA, et al. The prognosis of ankle sprains. International Journal of Sports Medicine 1997; 18 (4): 285-9

20. MacAuley D. Ankle injuries: same joint, different sports. Medicine and Science in Sports and Exercise 1999; 31 (7 Suppl): S409-11

21. Yeung MS, Chan KM, So $\mathrm{CH}$, et al. An epidemiological survey on ankle sprain. British Journal of Sports Medicine 1994; 28 (2): 112-6

22. McLennan JG, Ungersma J. Mountaineering accidents in the Sierra Nevada. American Journal of Sports Medicine 1983; 11 (3): 160-3

23. Yde J, Nielsen AB. Sports injuries in adolescents' ball games: soccer, handball and basketball. British Journal of Sports Medicine 1990; 24 (1): 51-4

24. Verhagen EA, Van der Beek AJ, Bouter LM, et al. A one season prospective cohort study of volleyball injuries. British Journal of Sports Medicine 2004; 38 (4): 477-81

25. Sullivan JA, Gross RH, Grana WA, et al. Evaluation of injuries in youth soccer. American Journal of Sports Medicine 1980; 8 (5): 325-327

26. Jacobson BH, Redus B, Palmer $\mathrm{T}$. An assessment of injuries in college cheerleading: distribution, frequency, and associated factors. British Journal of Sports Medicine 2005; 39 (4): 237-240

27. Kirialanis $\mathrm{P}$, Malliou $\mathrm{P}$, Beneka $\mathrm{A}$, et al. Injuries in artistic gymnastic elite adolescent male and female athletes. Journal of Back and Musculoskeletal Rehabilitation 2002; 16 (4): 145-151

28. Janda DH, Wojtys EM, Hankin FM, et al. A three-phase analysis of the prevention of recreational softball injuries. American Journal of Sports Medicine 1990; 18 (6): 632-5

29. Wheeler BR. Slow-pitch softball injuries. American Journal of Sports Medicine 1984; 12 (3): 237-40

30. Wikstrom J, Andersson C. A prospective study of injuries in licensed floorball 
players. Scandinavian Journal of Medicine and Science in Sports 1997; 7 (1): 38-42 31. Berson BL, Rolnick AM, Ramos CG, et al. An epidemiologic study of squash injuries. American Journal of Sports Medicine 1981; 9 (2): 103-6

32. Linko PE, Blomberg HK, Frilander HM. Orienteering competition injuries: injuries incurred in the Finnish Jukola and Venla relay competitions. British Journal of Sports Medicine 1997; 31 (3): 205-208

33. Mankovsky AB, Mendoza-Sagaon M, Cardinaux C, et al. Evaluation of scooter-related injuries in children. Journal of Pediatric Surgery 2002; 37 (5): 755-759 34. Brynhildsen J, Ekstrand J, Jeppsson A, et al. Previous injuries and persisting symptoms in female soccer players. International Journal of Sports Medicine 1990; 11 (6): 489-492

35. Dubravcic-Simunjak S, Pecina M, Kuipers $\mathrm{H}$, et al. The incidence of injuries in elite junior figure skaters. American Journal of Sports Medicine 2003; 31 (4): 511-7

36. Orchard J, Wood T, Seward H, et al. Comparison of injuries in elite senior and junior Australian football. Journal of Science and Medicine in Sport 1998; 1 (2): 83-8 37. Gerrard DF, Waller AE, Bird YN. The New Zealand rugby injury and performance project: II. previous injury experience of a rugby-playing cohort. British Journal of Sports Medicine 1994; 28 (4): 229-233

38. Murtaugh K. Injury patterns among female field hockey players. Medicine and Science in Sports and Exercise 2001; 33 (2): 201-207

39. Seil R, Rupp S, Tempelhof S, et al. Sports injuries in team handball. A one-year prospective study of sixteen men's senior teams of a superior nonprofessional level. American Journal of Sports Medicine 1998; 26 (5): 681-7

40. Gerber JP, Williams GN, Scoville CR, et al. Persistent disability associated with ankle sprains: a prospective examination of an athletic population. Foot and Ankle International 1998; 19 (10): 653-60

41. Woods C, Hawkins R, Hulse M, et al. The Football Association Medical Research Programme: an audit of injuries in professional football: an analysis of ankle sprains. British Journal of Sports Medicine 2003; 37 (3): 233-8

42. van Mechelen W, Hlobil H, Kemper HCG. Incidence, severity, aetiology and prevention of sports injuries: a review of concepts. Sports Medicine 1992; 14 (2): 82-99

43. Bahr R, Holme I. Risk factors for sports injuries--a methodological approach. British Journal of Sports Medicine 2003; 37 (5): 384-92

44. Giza E, Fuller C, Junge A, et al. Mechanisms of foot and ankle injuries in soccer. American Journal of Sports Medicine 2003; 31 (4): 550-4

45. Aguinaldo A, Mahar A. Impact loading in running shoes with cushioning column systems. Journal of Applied Biomechanics 2003; 19 (4): 353-360 
46. Osborne MD, Rizzo TD, Jr. Prevention and treatment of ankle sprain in athletes. Sports Medicine 2003; 33 (15): 1145-50

47. Cordova ML, Ingersoll CD, Palmieri RM. Efficacy of prophylactic ankle support: an experimental perspective. Journal of Athletic Training 2002; 37 (4): 446-457

48. Karlsson J, Andreasson GO. The effect of external ankle support in chronic lateral ankle joint instability. An electromyographic study. American Journal of Sports Medicine 1992; 20 (3): 257-61

49. Bronner S, Brownstein B. Profile of dance injuries in a Broadway show: a discussion of issues in dance medicine epidemiology. Journal of Orthopaedic and Sports Physical Therapy 1997; 26 (2): 87-94

50. Canale ST, Cantler ED, Sisk TD, et al. A chronicle of injuries of an American intercollegiate football team. American Journal of Sports Medicine 1981; 9 (6): 384-389

51. Ekstrand J, Gillquist J. Soccer injuries and their mechanisms: a prospective study. Medicine and Science in Sports and Exercise 1983; 15 (3): 267-70

52. Kibler WB. Injuries in adolescent and preadolescent soccer players. Medicine and Science in Sports and Exercise 1993; 25 (12): 1330-1332

53. Montorsi A, Sacchetti G, Boschi S, et al. Trauma epidemiology and injury mechanisms in volleyball. Journal of Sports Traumatology and Related Research 2000; 22 (4): 159-171

54. Paulseth S, Martinovich J, Scira J, et al. A study of training programs, types and incidents of injuries in elite male beach volleyball players. International Journal of Volleyball Research 2002; 5 (1): 6-12

55. Peterson L, Junge A, Chomiak J, et al. Incidence of football injuries and complaints in different age groups and skill-level groups. American Journal of Sports Medicine 2000; 28 (5 Suppl): S51-7

56. Stuart MJ, Morrey MA, Smith AM, et al. Injuries in youth football: a prospective observational cohort analysis among players aged 9 to 13 years. Mayo Clinic Proceedings 2002; 77 (4): 317-22

57. Zelisko JA, Noble HB, Porter M. A comparison of men's and women's professional basketball injuries. American Journal of Sports Medicine 1982; 10 (5): 297-299

58. Taylor BL, Attia MW. Sports-related injuries in children. Academic Emergency Medicine 2000; 7 (12): 1376-1382

59. Watson MD, DiMartino PP. Incidence of injuries in high school track and field athletes and its relation to performance ability. American Journal of Sports Medicine 1987; 15 (3): 251-4

60. Fordham S, Garbutt G, Lopes P. Epidemiology of injuries in adventure racing 
athletes. British Journal of Sports Medicine 2004; 38 (3): 300-303

61. Sinha A, McGlone RG, Montgomery K. Study of aeroball injuries. British Journal of Sports Medicine 1997; 31 (3): 200-4

62. Baltzer AW, Ghadamgahi PD, Granrath M, et al. American football injuries in Germany. First results from Bundesliga football. Knee Surgery Sports Traumatology Arthroscopy 1997; 5 (1): 46-9

63. Chomiak J, Junge A, Peterson L, et al. Severe injuries in football players. Influencing factors. American Journal of Sports Medicine 2000; 28 (5 Suppl): S58-68 64. Damore DT, Metzl JD, Ramundo M, et al. Patterns in childhood sports injury. Pediatric Emergency Care 2003; 19 (2): 65-67

65. DeLee JC, Farney WC. Incidence of injury in Texas high school football. American Journal of Sports Medicine 1992; 20 (5): 575-80

66. Hoffman MD, Lyman KA. Medical needs at high school football games in Milwaukee. Journal of Orthopaedic and Sports Physical Therapy 1988; 10 (5): 167-171

67. Karpakka J. American football injuries in Finland. British Journal of Sports Medicine 1993; 27 (2): 135-7

68. Marshall SW, Waller AE, Dick RW, et al. An ecologic study of protective equipment and injury in two contact sports. International Journal of Epidemiology 2002; 31 (3): 587-592

69. Braham R, Finch CF, McIntosh A, et al. Community level Australian Football: a profile of injuries. Journal of Science and Medicine in Sport 2004; 7 (1): 96-105

70. Gabbe B, Finch C. A profile of Australian football injuries presenting to sports medicine clinics. Journal of Science and Medicine in Sport 2001; 4 (4): 386-95

71. Gabbe B, Finch C, Wajswelner H, et al. Australian football: Injury profile at the community level. Journal of Science and Medicine in Sport 2002; 5 (2): 149-160

72. Gabbe BJ, Finch CF, Wajswelner H, et al. Predictors of lower extremity injuries at the community level of Australian football. Clinical Journal of Sport Medicine 2004; 14 (2): 56-63

73. Chard MD, Lachmann SM. Racquet sports--patterns of injury presenting to a sports injury clinic. British Journal of Sports Medicine 1987; 21 (4): 150-3

74. Fahlstrom M, Bjornstig U, Lorentzon R. Acute badminton injuries. Scandinavian Journal of Medicine and Science in Sports 1998; 8 (3): 145-8

75. Jorgensen U, Winge S. Epidemiology of badminton injuries. International Journal of Sports Medicine 1987; 8 (6): 379-382

76. Kroner K, Schmidt SA, Nielsen AB, et al. Badminton injuries. British Journal of Sports Medicine 1990; 24 (2): 169-172

77. Chan KM, Fu F, Leung L. Sports injuries survey on university students in Hong 
Kong. British Journal of Sports Medicine 1984; 18 (3): 195-202

78. Chan KM, Yuan Y, Li CK, et al. Sports causing most injuries in Hong Kong. British Journal of Sports Medicine 1993; 27 (4): 263-7

79. Dane S, Can S, Gursoy R, et al. Sport injuries: relations to sex, sport, injured body region. Perceptual and Motor Skills 2004; 98 (2): 519-24

80. DeHaven KE, Lintner DM. Athletic injuries: comparison by age, sport, and gender. American Journal of Sports Medicine 1986; 14 (3): 218-24

81. Gomez E, DeLee JC, Farney WC. Incidence of injury in Texas girls' high school basketball. American Journal of Sports Medicine 1996; 24 (5): 684-7

82. McKay GD, Payne WR, Goldie PA, et al. A comparison of the injuries sustained by female basketball and netball players. The Australian Journal of Science and Medicine in Sport 1996; 28 (1): 12-17

83. McKay GD, Goldie PA, Payne WR, et al. A prospective study of injuries in basketball: a total profile and comparison by gender and standard of competition. Journal of Science and Medicine in Sport 2001; 4 (2): 196-211

84. Meeuwisse WH, Sellmer R, Hagel BE. Rates and risks of injury during intercollegiate basketball. American Journal of Sports Medicine 2003; 31 (3): 379-85 85. Messina DF, Farney WC, DeLee JC. The incidence of injury in Texas high school basketball. A prospective study among male and female athletes. American Journal of Sports Medicine 1999; 27 (3): 294-9

86. Prebble TB, Chyou PH, Wittman L, et al. Basketball injuries in a rural area. Wisconsin Medical Journal 1999; 98 (7): 22-4

87. Sorensen L, Larsen SE, Rock ND. The epidemiology of sports injuries in school-ages children. Scandinavian Journal of Medicine and Science in Sports 1996; 6 (5): 281-286

88. Starkey C. Injuries and illnesses in the National Basketball Association: A 10-year. Journal of Athletic Training 2000; 35 (2): 161-167

89. Romaine LJ, Davis SE, Casebolt K, et al. Incidence of injury in kickboxing participation. Journal of Strength and Conditioning Research 2003; 17 (3): 580-6

90. Jacobson BH, Hubbard M, Redus B, et al. An assessment of high school cheerleading: injury distribution, frequency, and associated factors. Journal of Orthopaedic and Sports Physical Therapy 2004; 34 (5): 261-265

91. Schulz M, Marshall S, Yang J, et al. A prospective cohort study of injury incidence and risk factors in North Carolina High School competitive cheerleaders. American Journal of Sports Medicine 2004; 32 (2): 396-405

92. Gregory PL, Batt ME, Wallace WA. Comparing injuries of spin bowling with fast bowling in young cricketers. Clinical Journal of Sport Medicine 2002; 12 (2): 107-112 
93. Collins K, Wagner M, Peterson K, et al. Overuse injuries in triathletes. A study of the 1986 Seafair Triathlon. American Journal of Sports Medicine 1989; 17 (5): 675-80 94. Weiss BD. Nontraumatic injuries in amateur long distance bicyclists. American Journal of Sports Medicine 1985; 13 (3): 187-92

95. Byhring S, Bo K. Musculoskeletal injuries in the Norwegian national balley: a prospective cohort study. Scandinavian Journal of Medicine and Science in Sports 2002; 12 (6): 365-370

96. Nilsson C, Leanderson J, Wykman A, et al. The injury panorama in a Swedish professional ballet company. Knee Surgery Sports Traumatology Arthroscopy 2001; 9 (4): $242-246$

97. Rothenberger LA, Chang JI, Cable TA. Prevalence and types of injuries in aerobic dancers. American Journal of Sports Medicine 1988; 16 (4): 403-407

98. Tuffery AR. The nature and incidence of injuries in morris dancers. British Journal of Sports Medicine 1989; 23 (3): 155-160

99. Wiesler ER, Hunter M, Martin DF, et al. Ankle flexibility and injury patterns in dancers. American Journal of Sports Medicine 1996; 24 (6): 754-757

100. Petridou E, Kedikoglou S, Belechri M, et al. The mosaic of equestrian-related injuries in Greece. Journal of Trauma 2004; 56 (3): 643-7

101. Goel A, Addison AKL. Fell walking injuries in Cumbria: a review. British Journal of Sports Medicine 1992; 26 (3): 143-14

102. Williamson DM, Lowdon IM. Ice-skating injuries. Injury 1986; 17 (3): 205-7

103. Collins RK. Injury patterns in women's intramural flag football. American Journal of Sports Medicine 1987; 15 (3): 238-242

104. Snellman K, Parkkari J, Kannus P, et al. Sports injuries in floorball: A prospective one-year follow-up study. International Journal of Sports Medicine 2001; 22 (7): 531-536

105. Cromwell F, Walsh J, Gormley J. A pilot study examining injuries in elite gaelic footballers. British Journal of Sports Medicine 2000; 34 (2): 104-8

106. Batt ME. A survey of golf injuries in amateur golfers. British Journal of Sports Medicine 1992; 26 (1): 63-65

107. Gosheger G, Liem D, Ludwig K, et al. Injuries and overuse syndromes in golf. American Journal of Sports Medicine 2003; 31 (3): 438-43

108. Kirialanis P, Malliou P, Beneka A, et al. Occurrence of acute lower limb injuries in artistic gymnasts in relation to event and exercise phase. British Journal of Sports Medicine 2003; 37 (2): 137-9

109. Kolt GS, Kirkby RJ. Epidemiology of injury in elite and subelite female gymnasts: a comparison of retrospective and prospective findings. British Journal of Sports Medicine 1999; 33 (5): 312-8 
110. Lindner KJ, Caine DJ. Injury patterns of female competitive club gymnasts. Canadian Journal of Sport Science 1990; 15 (4): 254-261

111. Tenvergert EM, Ten Duis HJ, Klasen HJ. Trends in sports injuries, 1982-1988: an in-depth study on four types of sport. Journal of Sports Medicine and Physical Fitness 1992; 32 (2): 214-20

112. Wadley GH, Albright JP. Women's intercollegiate gymnastics. Injury patterns and "permanent" medical disability. American Journal of Sports Medicine 1993; 21 (2): $314-20$

113. Jorgensen U. Epidemiology of injuries in typical Scandinavian team sports. British Journal of Sports Medicine 1984; 18 (2): 59-63

114. Nielsen AB, Yde J. An epidemiologic and traumatologic study of injuries in handball. International Journal of Sports Medicine 1988; 9 (5): 341-344

115. Crowley PJ, Condon KC. Analysis of hurling and camogie injuries. British Journal of Sports Medicine 1989; 23 (3): 183-185

116. Watson AW. Sports injuries in the game of hurling. A one-year prospective study. American Journal of Sports Medicine 1996; 24 (3): 323-8

117. Flik K, Lyman S, Marx RG. American collegiate men's ice hockey. American Journal of Sports Medicine 2005; 33 (2): 183-187

118. Jorgensen U, Schmidt-Olsen S. The epidemiology of ice hockey injuries. British Journal of Sports Medicine 1986; 20 (1): 7-9

119. Molsa J, Airaksinen O, Nasman O, et al. Ice hockey injuries in Finland - a prospective epidemiological study. American Journal of Sports Medicine 1997; 25 (4): 495-499

120. Pettersson M, Lorentzon R. Ice hockey injuries: a 4-year prospective study of a Swedish elite ice hockey team. British Journal of Sports Medicine 1993; 27 (4): 251-254

121. Schick DM, Meeuwisse WH. Injury rates and profiles in female ice hockey players. American Journal of Sports Medicine 2003; 31 (1): 47-52

122. Waller AE, Daniels JL, Weaver NL, et al. Jockey injuries in the United States. JAMA 2000; 283 (10): 1326-8

123. Nickel C, Zernial O, Musahl V, et al. A prospective study of kitesurfing injuries. American Journal of Sports Medicine 2004; 32 (4): 921-7

124. Hinton RY, Lincoln AE, Almquist JL, et al. Epidemiology of lacrosse injuries in high school-aged girls and boys: a 3-year prospective study. American Journal of Sports Medicine 2005; 33 (9): 1305-14

125. Cummings RS, Shurland AT, Prodoehl JA, et al. Injuries in the sport of luge epidemiology and analysis. American Journal of Sports Medicine 1997; 25 (4): 508-513 
126. Maughan RJ, Miller JDB. Incidence of training-related injuries among marathon runners. British Journal of Sports Medicine 1983; 17 (3): 162-165

127. Burks JB, Satterfield K. Foot and ankle injuries among martial artists. Results of a survey. Journal of the American Podiatric Medical Association 1998; 88 (6): 268-78 128. Colburn NT, Meyer RD. Sports injury or trauma? Injuries of the competition off-road motorcyclist. Injury 2003; 34 (3): 207-14

129. Tomida Y, Hirata H, Fukuda A, et al. Injuries in elite motorcycle racing in Japan. British Journal of Sports Medicine 2005; 39 (8): 508-11

130. Hopper D, Elliott B, Lalor J. A descriptive epidemiology of netball injuries during competition: a five year study. British Journal of Sports Medicine 1995; 29 (4): 223-8

131. Hume PA. Netball injuries in New Zealand. New Zealand Journal of Sports Medicine 1993; 21 (2): 27-31

132. Hume PA, Steele JR. A preliminary investigation of injury prevention strategies in Netball: are players heeding the advice? Journal of Science and Medicine in Sport 2000; 3 (4): 406-13

133. Smith R, Damodaran AK, Swaminathan S, et al. Hypermobility and sports injuries in junior netball players. British Journal of Sports Medicine 2005; 39 (9): 628-31

134. Creagh U, Reilly T. Training and injuries amongst elite female orienteers. Journal of Sports Medicine and Physical Fitness 1998; 38 (1): 75-9

135. Folan JM. Orienteering injuries. British Journal of Sports Medicine 1982; 16 (4): 236-240

136. Johansson C. Injuries in elite orienteers. American Journal of Sports Medicine 1986; 14 (5): 410-5

137. Linde F. Injuries in orienteering. British Journal of Sports Medicine 1986; 20 (3): $125-7$

138. Petras AF, Hoffman EP. Roentgenographic skeletal injury patterns in parachute jumping. American Journal of Sports Medicine 1983; 11 (5): 325-328

139. Steinberg PJ. Injuries to Dutch sport parachutists. British Journal of Sports Medicine 1988; 22 (1): 25-30

140. Kruger-Franke M, Siebert CH, Pforringer W. Paragliding injuries. British Journal of Sports Medicine 1991; 25 (2): 98-101

141. Butterwick DJ, Hagel B, Nelson DS, et al. Epidemiologic analysis of injury in five years of Canadian professional rodeo. American Journal of Sports Medicine 2002; 30 (2): 193-8

142. Bunker TD. The 1982 epidemic--roller skating injuries. British Journal of Sports Medicine 1983; 17 (3): 205-7 
143. Ferkel RD, Mai LL, Ullis KC, et al. An analysis of roller skating injuries. American Journal of Sports Medicine 1982; 10 (1): 24-30

144. Kvidera DJ, Frankel VH. Trauma on eight wheels. A study of roller skating injuries in Seattle. American Journal of Sports Medicine 1983; 11 (1): 38-41

145. Tse PY, Shen WY, Chan KM, et al. Roller skating--is it a dangerous sport? British Journal of Sports Medicine 1987; 21 (3): 125-6

146. Goh SH, Tan HK, Yong WS, et al. Spectrum of roller-blading injuries. Annals of the Academy of Medicine Singapore 1996; 25 (4): 547-9

147. Nguyen D, Letts M. In-line skating injuries in children: a 10-year review. Journal of Pediatric Orthopedics 2001; 21 (5): 613-8

148. Schuster M, Istaeli A. Survey of injuries and protective gear worn by in-line skaters in public parks. American Journal of Physical Medicine and Rehabilitation 1999; 78 (1): 7-10

149. Babic Z, Misigoj-Durakovic M, Matasic H, et al. Croatian rugby project. Part II: injuries. Journal of Sports Medicine and Physical Fitness 2001; 41 (3): 392-8

150. Best JP, McIntosh AS, Savage TN. Rugby World Cup 2003 injury surveillance project. British Journal of Sports Medicine 2005; 39 (11): 812-7

151. Bottini E, Poggi EJ, Luzuriaga F, et al. Incidence and nature of the most common rugby injuries sustained in Argentina (1991-1997). British Journal of Sports Medicine 2000; 34 (2): 94-7

152. Brooks JH, Fuller CW, Kemp SP, et al. Epidemiology of injuries in English professional rugby union: part 1 match injuries. British Journal of Sports Medicine 2005; 39 (10): 757-66

153. Brooks JH, Fuller CW, Kemp SP, et al. Epidemiology of injuries in English professional rugby union: part 2 training Injuries. British Journal of Sports Medicine 2005; 39 (10): 767-75

154. Marshall SW, Waller AE, Loomis DP, et al. Use of protective equipment in a cohort of rugby players. Medicine and Science in Sports and Exercise 2001; 33 (12): 2131-2138

155. Stephenson S, Gissane C, Jennings D. Injury in rugby league: a four year prospective survey. British Journal of Sports Medicine 1996; 30 (4): 331-334

156. D'Souza D. Track and field athletics injuries--a one-year survey. British Journal of Sports Medicine 1994; 28 (3): 197-202

157. Lun V, Meeuwisse WH, Stergiou P, et al. Relation between running injury and static lower limb alignment in recreational runners. British Journal of Sports Medicine 2004; 38 (5): 576-80

158. Aslam N, Gwilym S, Apostolou C, et al. Microscooter injuries in the paediatric population. European Journal of Emergency Medicine 2004; 11 (3): 148-50 
159. Forsman L, Eriksson A. Skateboarding injuries of today. British Journal of Sports Medicine 2001; 35 (5): 325-8

160. Bladin C, Giddings P, Robinson M. Australian snowboard injury data base study. A four-year prospective study. American Journal of Sports Medicine 1993; 21 (5): $701-4$

161. Blitzer CM, Johnson RJ, Ettlinger CF, et al. Downhill skiing injuries in children. American Journal of Sports Medicine 1984; 12 (2): 142-7

162. Bridges EJ, Rouah F, Johnston KM. Snowblading injuries in Eastern Canada. British Journal of Sports Medicine 2003; 37 (6): 511-5

163. Davidson TM, Laliotis AT. Snowboarding injuries, a four-year study with comparison with alpine ski injuries. Western Journal of Medicine 1996; 164 (3): 231-7

164. Sherry E, Asquith J. Nordic (cross-country) skiing injuries in Australia. The Medical Journal of Australia 1987; 146 (5): 245-246

165. Sylvest A, Lund NA, Lauritzen JB, et al. Skiing injuries among Danes in Austin. Scandinavian Journal of Medicine and Science in Sports 1991; 1 (4): 225-227

166. Ungerholm S, Engkvist O, Gierup J, et al. Skiing injuries in children and adults: a comparative study from a 8-year period. International Journal of Sports Medicine 1983; 4 (4): 236-240

167. Williams RL, Sweetnam DIS, Stanislas M. Skiing injuries: the increasing workload. British Journal of Sports Medicine 1995; 29 (4): 252-254

168. Federiuk CS, Mann NC. Telemark skiing injuries: characteristics and risk factors. Wilderness and Environmental Medicine 1999; 10 (4): 233-41

169. Made C, Borg H, Thelander D, et al. Telemark skiing injuries: an 11-year study. Knee Surgery Sports Traumatology Arthroscopy 2001; 9 (6): 386-91

170. Abu-Laban RB. Snowboarding injuries: an analysis and comparison with alpine skiing injuries. Canadian Medical Association Journal 1991; 145 (9): 1097-1103

171. Pino EC, Colville MR. Snowboard injuries. American Journal of Sports Medicine 1989; 17 (6): 778-781

172. Torjussen J, Bahr R. Injuries among competitive snowboarders at the national elite level. American Journal of Sports Medicine 2005; 33 (3): 370-7 173. Andersen TE, Tenga A, Engebretsen L, et al. Video analysis of injuries and incidents in Norwegian professional football. British Journal of Sports Medicine 2004; 38 (5): 626-31

174. Arnason A, Sigurdsson SB, Gudmundsson A, et al. Risk factors for injuries in football. American Journal of Sports Medicine 2004; 32 (1 Suppl): 5S-16S

175. Drawer S, Fuller CW. Propensity for osteoarthritis and lower limb joint pain in retired professional soccer players. British Journal of Sports Medicine 2001; 35 (6): 
402-8

176. Elias SR. 10-year trend in USA Cup soccer injuries: 1988-1997. Medicine and Science in Sports and Exercise 2000; 33 (3): 359-367

177. Engstrom B, Johansson C, Tornkvist H. Soccer injuries among elite female players. American Journal of Sports Medicine 1991; 19 (4): 372-375

178. Faude O, Junge A, Kindermann W, et al. Injuries in female soccer players: a prospective study in the German national league. American Journal of Sports Medicine 2005; 33 (11): 1694-700

179. Giza E, Mithofer K, Farrell L, et al. Injuries in women's professional soccer. British Journal of Sports Medicine 2005; 39 (4): 212-216

180. Hagglund M, Walden M, Ekstrand J. Injury incidence and distribution in elite football--a prospective study of the Danish and the Swedish top divisions.[see comment]. Scandinavian Journal of Medicine and Science in Sports 2005; 15 (1): 21-8

181. Hawkins RD, Fuller CW. A prospective epidemiological study of injuries in four English professional football clubs. British Journal of Sports Medicine 1999; 33 (3): 196-203

182. Hawkins RD, Hulse MA, Wilkinson C, et al. The association football medical research programme: an audit of injuries in professional football. British Journal of Sports Medicine 2001; 35 (1): 43-47

183. Inklaar H, Bol E, Schmikli SL, et al. Injuries in male soccer players: team risk analysis. International Journal of Sports Medicine 1996; 17 (3): 229-234

184. Junge A, Dvorak J, Graf-Baumann T, et al. Football injuries during FIFA tournaments and the Olympic Games, 1998-2001. American Journal of Sports Medicine 2004; 32 (1): S80-89

185. Lilley K, Gass E, Locke S. A retrospective injury analysis of state representative female soccer players. Physical Therapy in Sport 2002; 3 (1): 2-9

186. McMaster WC, Walter M. Injuries in soccer. American Journal of Sports Medicine 1978; 6 (6): 354-357

187. Morgan BE, Oberlander MA. An examination of injuries in major league soccer. The inaugural season. American Journal of Sports Medicine 2001; 29 (4): 426-30

188. Nielsen AB, Yde J. Epidemiology and traumatology of injuries in soccer. American Journal of Sports Medicine 1989; 17 (6): 803-807

189. Ostenberg A, Roos H. Injury risk factors in female European football. A prospective study of 123 players during one season. Scandinavian Journal of Medicine and Science in Sports 2000; 10 (5): 279-85

190. Price RJ, Hawkins RD, Hulse MA, et al. The Football Association medical research programme: an audit of injuries in academy youth football. British Journal of 
Sports Medicine 2004; 38 (4): 466-71

191. Schmidt-Olsen S, Bunemann LK, Lade V, et al. Soccer injuries of youth. British Journal of Sports Medicine 1985; 19 (3): 161-4

192. Schmidt-Olsen S, Jorgensen U, Kaalund S, et al. Injuries among young soccer players. American Journal of Sports Medicine 1991; 19 (3): 273-275

193. Soderman K, Alfredson H, Pietila T, et al. Risk factors for leg injuries in female soccer players: a prospective investigation during one out-door season. Knee Surgery Sports Traumatology Arthroscopy 2001; 9 (5): 313-321

194. Soderman K, Adolphson J, Lorentzon R, et al. Injuries in adolescent female players in European football: a prospective study over one outdoor soccer season. Scandinavian Journal of Medicine and Science in Sports 2001; 11 (5): 299-304

195. Walden M, Hagglund M, Ekstrand J. Injuries in Swedish elite football - a prospective study on injury definitions, risk for injury and injury pattern during 2001. Scandinavian Journal of Medicine and Science in Sports 2005; 15 (2): 118-125

196. Walden M, Hagglund M, Ekstrand J. UEFA Champions League study: a prospective study of injuries in professional football during the 2001-2002 season. British Journal of Sports Medicine 2005; 39 (8): 542-6

197. Yoon YS, Chai M, Shin DW. Football injuries at Asian tournaments. American Journal of Sports Medicine 2004; 32 (1 Suppl): 36S-42S

198. Lindenfeld TN, Schmitt DJ, Hendy MP, et al. Incidence of injury in indoor soccer. American Journal of Sports Medicine 1994; 22 (3): 364-71

199. Putukian M, Knowles WK, Swere S, et al. Injuries in indoor soccer. The Lake Placid Dawn to Dark Soccer Tournament. American Journal of Sports Medicine 1996; 24 (3): 317-22

200. Loosli AR, Requa RK, Garrick JG, et al. Injuries to pitchers in women's collegiate fast-pitch softball. American Journal of Sports Medicine 1992; 20 (1): 35-7 201. Quinn A, Lun V, McCall J, et al. Injuries in short track speed skating. American Journal of Sports Medicine 2003; 31 (4): 507-10

202. Feehan M, Waller AE. Precompetition injury and subsequent tournament performance in full-contact taekwondo. British Journal of Sports Medicine 1995; 29 (4): 258-262

203. Hutchinson MR, Laprade RF, Burnett QM, 2nd, et al. Injury surveillance at the USTA Boys' Tennis Championships: a 6-yr study. Medicine and Science in Sports and Exercise 1995; 27 (6): 826-30

204. Silva RT, Takahashi R, Berra B, et al. Medical assistance at the Brazilian juniors tennis circuit--a one-year prospective study. Journal of Science and Medicine in Sport 2003; 6 (1): 14-8

205. Neumann DC, McCurdie IM, Wade AJ. A survey of injuries sustained in the 
game of touch. Journal of Science and Medicine in Sport 1998; 1 (4): 228-35

206. Chalmers DJ, Hume PA, Wilson BD. Trampolines in New Zealand: a decade of injuries. British Journal of Sports Medicine 1994; 28 (4): 234-238

207. Hume PA, Chalmers DJ, Wilson BD. Trampoline injury in New Zealand: emergency care. British Journal of Sports Medicine 1996; 30 (4): 327-330

208. Korkia PK, Tunstall-Pedoe DS, Maffulli N. An epidemiological investigation of training and injury patterns in British triathletes. British Journal of Sports Medicine 1994; 28 (3): 191-6

209. Williams MM, Hawley JA, Black R, et al. Injuries amongst competitive triathletes. Physiotherapy in Sport 1988; 11 (3): 13-15

210. Smith J, Krabak B. Tug of war: introduction to the sport and an epidemiological injury study among elite pullers. Scandinavian Journal of Medicine and Science in Sports 2002; 12 (2): 117-124

211. Marfleet P. Ultimate injuries: a survey. British Journal of Sports Medicine 1991; 25 (4): 235-40

212. Bishop GW, Fallon KE. Musculoskeletal injuries in a six-day track race: ultramarathoner's ankle. Clinical Journal of Sport Medicine 1999; 9 (4): 216-20

213. Fallon KE. Musculoskeletal injuries in the ultramarathon: the 1990 Westfield Sydney to Melbourne run. British Journal of Sports Medicine 1996; 30 (4): 319-23 214. Aagaard H, Jorgensen U. Injuries in elite volleyball. Scandinavian Journal of Medicine and Science in Sports 1996; 6 (4): 228-232

215. Aagaard H, Scavenius M, Jorgensen U. An epidemiological analysis of the injury pattern in indoor and in beach volleyball. International Journal of Sports Medicine 1997; 18 (3): 217-221

216. Schafle MD, Requa RK, Patton WL, et al. Injuries in the 1987 National Amateur Volleyball Tournament. American Journal of Sports Medicine 1990; 18 (6): 624-631 217. Solgard L, Nielsen AB, Moller-Madsen B, et al. Volleyball injuries presenting in casualty: a prospective study. British Journal of Sports Medicine 1995; 29 (3): 200-4 218. Bahr R, Reeser JC. Injuries among world-class professional beach volleyball players. The Federation Internationale de Volleyball beach volleyball injury study. American Journal of Sports Medicine 2003; 31 (1): 119-25

219. Hostetler SG, Hostetler TL, Smith GA, et al. Characteristics of water skiing-related and wakeboarding-related injuries treated in emergency departments in the United States, 2001-2003. American Journal of Sports Medicine 2005; 33 (7): 1065-70

220. Limb D. Injuries on British climbing walls. British Journal of Sports Medicine 1995; 29 (3): 168-170

221. Nathanson AT, Reinert SE. Windsurfing injuries: results of a paper- and 
internet-based survey. Wilderness and Environmental Medicine 1999; 10 (4): 218-225 222. Jarvinen TA, Jarvinen TL, Kaariainen M, et al. Muscle injuries: biology and treatment. American Journal of Sports Medicine 2005; 33 (5): 745-64

223. Hosea TM, Carey CC, Harrer MF. The gender issue: epidemiology of ankle injuries in athletes who participate in basketball. Clinical Orthopaedics and Related Research 2000; (372): 45-9

224. Kirkpatrick DP, Hunter RE, Janes PC, et al. The snowboarder's foot and ankle. American Journal of Sports Medicine 1998; 26 (2): 271-7

225. Andersen TE, Floerenes TW, Arnason A, et al. Video analysis of the mechanisms for ankle injuries in football. American Journal of Sports Medicine 2004; 32 (1 Suppl): 69S-79S

226. Woods C, Hawkins R, Hulse M, et al. The Football Association Medical Research Programme: an audit of injuries in professional football-analysis of preseason injuries. British Journal of Sports Medicine 2002; 36 (6): 436-41; discussion 441

227. Mummery WK, Spence JC, Vincenten JA, et al. A descriptive epidemiology of sport and recreation injuries in a population-based sample: results from the Alberta Sport and Recreation Injury Survey (ASRIS). Canadian Journal of Public Health 1998; 89 (1): 53-6

228. Kannus P, Aho H, Jarvinen M, et al. Computerized recording of visits to an outpatient sports clinic. American Journal of Sports Medicine 1987; 15 (1): 79-85

229. Kannus P, Niittymaki S, Jarvinen M. Sports injuries in women: a one-year prospective follow-up study at an outpatient sports clinic. British Journal of Sports Medicine 1987; 21 (1): 37-9

230. Sandelin J. Acute sports injuries requiring hospital care. British Journal of Sports Medicine 1986; 20 (3): 99-102

231. Backx FJ, Erich WB, Kemper AB, et al. Sports injuries in school-aged children. An epidemiologic study. American Journal of Sports Medicine 1989; 17 (2): 234-40 232. Kingma J, Ten Duis HJ. Injuries due to school sports accidents in 4 to 13-yr.-old children. Perceptual and Motor Skills 2000; 90 (1): 319-25

233. Maffuli N, Bundoc RC, Chan KM, et al. Paediatric sports injuries in Hong Kong: a seven year survey. British Journal of Sports Medicine 1996; 30 (3): 218-221

234. Sadat-Ali M, Sankaran-Kutty M. Sports injuries in Saudi Arabia. British Journal of Sports Medicine 1985; 19 (1): 28-29

235. Devereaux MD, Lachmann SM. Athletes attending a sports injury clinic--a review. British Journal of Sports Medicine 1983; 17 (4): 137-42

236. Galasko CSB, Menon TJ, Lemon GJ, et al. University of Manchester sports injury clinic. British Journal of Sports Medicine 1982; 16 (1): 23-26 
237. Nicholl JP, Coleman P, Williams BT. The epidemiology of sports and exercise related injury in the United Kingdom. British Journal of Sports Medicine 1995; 29 (4): 232-238

238. Rowell S, Rees-Jones A. Injuries treated at a sports injury clinic compared with a neighbouring accident and emergency department. British Journal of Sports Medicine 1988; 22 (4): 157-160

239. Watkins J, Peabody P. Sports injuries in children and adolescents treated at a sports injury clinic. Journal of Sports Medicine and Physical Fitness 1996; 36 (1): $43-48$

240. Almeida SA, Williams KM, Shaffer RA, et al. Epidemiological patterns of musculoskeletal injuries and physical training. Medicine and Science in Sports and Exercise 1999; 31 (8): 1176-1182

241. Austin GJ, Rogers KD, Reese G. Injuries in high school physical education classes. American Journal of Diseases of Children 1980; 134 (5): 456-8

242. Beachy G, Akau CK, Martinson M, et al. High school sports injuries - a longitudinal study at Punahou School: 1988 to 1996. American Journal of Sports Medicine 1997; 25 (5): 675-681

243. Jackson DS, Furman WK, Berson BL. Patterns of injuries in college athletes: a retrospective study of injuries sustained in intercolleagiate athletics in two college over a two-year period. The Mount Sinai Journal of Medicine 1980; 47 (4): 423-426

244. Thompson SH, Case AJ, Sargent RG. Factors influencing performance-related injuries among group exercise instructors. Women in Sport and Physical Activity Journal 2001; 10 (1): 125-142

245. Yang J, Marshall SW, Bowling JM, et al. Use of discretionary protective equipment and rate of lower extremity injury in high school athletes. American Journal of Epidemiology 2005; 161 (6): 511-519

246. McKay GD, Goldie PA, Payne WR, et al. Ankle injuries in basketball: injury rate and risk factors. British Journal of Sports Medicine 2001; 35 (2): 103-8

247. Jarret GJ, Orwin JF, Dick RW. Injuries in collegiate wrestling. American Journal of Sports Medicine 1998; 26 (5): 674-80

248. Shawdon A, Brukner P. Injury profile of amateur Australian rules footballers. The Australian Journal of Science and Medicine in Sport 1994; 26 (3-4): 59-61

249. Beynnon BD, Vacek PM, Murphy DF, et al. First-time inversion ankle ligament trauma - the effects of sex, level of competition, and sport on the incidence of injury. American Journal of Sports Medicine 2005; 33 (10): 1485-1491

250. Ekstrand J, Tropp H. The incidence of ankle sprains in soccer. Foot and Ankle International 1990; 11 (1): 41-4

251. Berger-Vachon C, Gabard G, Moyen B. Soccer accidents in the French 
Rhone-Alpes soccer association. Sports Medicine 1986; 3 (1): 69-77 
Table 1 - Distribution of geographical location of the included studies.

\begin{tabular}{|c|c|}
\hline Continent & Countries \\
\hline Europe (116) & $\begin{array}{l}\text { United Kingdom (34), Sweden (18), Denmark (16), Holland (9), } \\
\text { Finland (7), Germany (7), Norway (6), France (3), Greece (3), } \\
\text { Iceland (2), Croatia (2), Czechoslovakia (1), Turkey (1), } \\
\text { Switzerland (1), Austria (1), Belgium (1), Ireland (1), Italy (1), } \\
\text { Spain (1), Poland (1) }\end{array}$ \\
\hline N.America (77) & $\begin{array}{l}\text { United States (62), Canada (11), Mexico (2), Guatemala (1), } \\
\text { Dominica (1) }\end{array}$ \\
\hline Australasia (30) & Australia (21), New Zealand (9) \\
\hline Asia (11) & $\begin{array}{l}\text { Hong Kong (4), Japan (2), Korea (1), Saudi Arabia (1), Singapore } \\
\text { (1), Lebanon (1), Iran (1) }\end{array}$ \\
\hline S.America (5) & Argentina (2), Brazil (2), Trinidad and Tobago (1) \\
\hline Africa (1) & Nigeria (1) \\
\hline N/A (15) & \\
\hline
\end{tabular}

*Note: Total count exceeds the number of studies as some studies reported epidemiology findings in more than one country. 
Table 2 - Period of study, population investigated, nature of study and the case number of the included studies.

\begin{tabular}{llllllll}
\hline \multicolumn{3}{l}{ Period of study } & \multicolumn{3}{l}{ Population } & Nature of study & \multicolumn{2}{l}{ Case } \\
\hline Before 1980 & 17 & Team & 92 & Prospective & 171 & $1-100$ & 52 \\
$1981-85$ & 36 & Public & 67 & Retrospective & 43 & $101-500$ & 113 \\
$1986-90$ & 53 & Event & 35 & N/A & 13 & $501-1000$ & 25 \\
$1991-95$ & 56 & School & 25 & & & $1001-2000$ & 13 \\
$1996-00$ & 61 & Military & 2 & & $2001-5000$ & 13 \\
$2001-05$ & 26 & N/A & 6 & & $5001-10000$ & 10 \\
N/A & 37 & & & & & $>10000$ & 1 \\
\hline Total & $286 *$ & & 227 & & & 227 \\
\hline
\end{tabular}

* Total count exceeds the number of studies as some studies reported epidemiology findings in more than one period of time. 
Table 3 - Most common injured body sites in different sports and countries

\begin{tabular}{|c|c|c|c|c|c|c|}
\hline Sport & Most commol & ed body sites & & & & References \\
\hline Adventure Racing & Ankle (23.0) & Shoulder (11.5) & $\operatorname{Arm}(11.5)$ & Knee (11.0) & Trunk (11.0) & [60] \\
\hline Aeroball & Ankle (80.0) & Knee (9.2) & Foot (6.4) & Hand(3.7) & Head (2.8) & [61] \\
\hline American Football & Knee (21.0) & Ankle (17.0) & Shoulder (8.4) & Trunk (5.8) & Thigh (4.9) & {$[50,55,56,58,62-68]$} \\
\hline Australian Football & Thigh (19.6) & Knee (12.3) & Ankle (7.9) & Leg (4.5) & Head (3.8) & [36,69-72] \\
\hline Badminton & Ankle (23.5) & Knee (14.0) & Foot (12.5) & Arm (8.0) & Leg (5.4) & [73-76] \\
\hline Baseball & Head (41.0) & Hand (29.0) & Leg (8.0) & Arm (6.0) & Ankle (3.5) & [58] \\
\hline Basketball & Ankle (15.9) & Knee (10.7) & Trunk (6.5) & Thigh (5.4) & Leg (5.0) & {$[23,57,58,64,77-88]$} \\
\hline Cardio Kickboxing & Trunk (20.0) & Knee (18.0) & Hip (11.0) & Shoulder (10.0) & Thigh (8.0) & [89] \\
\hline Cheerleading & Ankle (26.2) & Knee (10.4) & Trunk (9.4) & Arm (7.0) & Head (6.9) & {$[26,90,91]$} \\
\hline Cricket & Ankle (17.9) & Knee (15.8) & Shoulder (14.7) & Trunk (12.6) & & [92] \\
\hline Cycling & Knee (24.3) & Hand (17.7) & Leg (11.9) & Foot (11.8) & & {$[64,77,93,94]$} \\
\hline Dancing & Leg (19.5) & Ankle (17.4) & Trunk (13.9) & Foot (12.0) & Knee (10.4) & {$[12,15,49,95-99]$} \\
\hline Equestrian & Arm (22.3) & Head (21.7) & Hand (15.6) & Thigh (8.8) & Leg (7.0) & {$[87,100]$} \\
\hline Fell Walking & Head (28.8) & Ankle (24.0) & Leg (13.6) & Hand (9.1) & Trunk (7.2) & [101] \\
\hline Field Hockey & Head (34.4) & Ankle (34.0) & Arm (13.6) & Knee (4.1) & Trunk (1.1) & [38] \\
\hline Figure Skating & Ankle (24.5) & Leg (18.0) & Knee (15.6) & Head (9.8) & Arm (9.2) & {$[35,102]$} \\
\hline Flag Football & Hand (39.0) & Knee (18.0) & Thigh (9.0) & Ankle (8.0) & Foot (4.0) & [103] \\
\hline Floorball & Ankle (26.8) & Knee (17.9) & Trunk (8.3) & Head (7.8) & Foot (5.1) & {$[30,104]$} \\
\hline Gaelic Football & Ankle (21.0) & Knee (13.0) & Thigh (13.0) & Shoulder (12.0) & Trunk (7.5) & [105] \\
\hline Golf & Trunk (25.6) & Arm (21.2) & Shoulder (15.8) & Hand (14.9) & Head (6.1) & {$[106,107]$} \\
\hline Gynmastics & Ankle (32.3) & Arm (25.9) & Knee (9.4) & Trunk (6.8) & Hand (4.4) & {$[14,27,87,108-112]$} \\
\hline
\end{tabular}




\begin{tabular}{|c|c|c|c|c|c|c|}
\hline Handball & Hand (31.2) & Ankle (13.5) & Knee (10.7) & Arm (6.9) & Leg (6.6) & {$[23,39,87,113,114]$} \\
\hline Hurling / Camogie & Hand (27.1) & Head (20.2) & Ankle (8.6) & Leg (8.4) & Head (6.5) & {$[115,116]$} \\
\hline Ice Hockey & Head (21.4) & Knee (14.7) & Thigh (10.6) & Trunk (6.1) & Shoulder (5.6) & {$[87,117-121]$} \\
\hline Jockey & Head (18.8) & Ankle (10.7) & Trunk (10.7) & Shoulder (9.6) & Knee (7.8) & [122] \\
\hline Kitesurfing & Ankle (14.1) & Foot (14.1) & Head (13.7) & Trunk (12.9) & Knee (12.9) & [123] \\
\hline Lacrosse & Knee (20.3) & Ankle (18.5) & Head (12.7) & Hand (9.9) & Shoulder (3.8) & [124] \\
\hline Luging & Head (12.8) & Hand (11.3) & Trunk (8.9) & Shoulder (7.6) & Knee (7.6) & [125] \\
\hline Marathon & Knee (31.7) & Foot (27.5) & Ankle (10.1) & Leg (6.8) & Thigh (1.3) & [126] \\
\hline Martial Arts & Arm (45.0) & Ankle (21.0) & Head (20.0) & Trunk (5.0) & Knee (4.4) & {$[111,127]$} \\
\hline Motorcycle Racing & Hand (22.4) & Arm (18.5) & Ankle (16.4) & Shoulder (14.6) & Knee (12.2) & {$[128,129]$} \\
\hline Mountaineering & Ankle (40.0) & Knee (10.7) & Foot (7.9) & Leg (7.4) & Arm (5.6) & [22] \\
\hline Netball & Ankle (39.8) & Knee (17.8) & Hand (10.5) & Head (8.7) & Leg (5.6) & [82,130-133] \\
\hline Orienteering & Ankle (29.8) & Knee (18.1) & Leg (14.8) & Foot (13.3) & Thigh (5.0) & [134-137] \\
\hline Parachuting & Ankle (32.9) & Leg (26.9) & Trunk (10.8) & Arm (3.1) & Hand (3.1) & {$[138,139]$} \\
\hline Paragliding & Trunk (34.9) & Ankle (21.0) & Arm (13.4) & Knee (2.8) & & [140] \\
\hline Rodeo & Knee (16.9) & Trunk (12.4) & Head (11.6) & Shoulder (9.3) & Ankle (5.1) & {$[141]$} \\
\hline Roller Skating & Arm (32.8) & Hand (30.6) & Ankle (7.5) & Head (3.7) & Shoulder (3.3) & {$[87,142-145]$} \\
\hline Rollerblading / Inline Skating & Hand (30.7) & Arm (16.4) & Knee (12.8) & Head (10.4) & Ankle (3.6) & {$[58,146-148]$} \\
\hline Rugby & Head (13.7) & Thigh (12.7) & Ankle (11.6) & Knee (9.7) & Leg (8.4) & {$[37,68,149-155]$} \\
\hline Running & Knee (28.9) & Ankle (20.2) & Foot (10.5) & Leg (7.6) & Thigh (4.7) & {$[78,79,93,156,157]$} \\
\hline Scooter & Ankle (30.5) & Arm (25.6) & Hand (20.7) & Knee (4.9) & Head (2.5) & {$[33,158]$} \\
\hline Skateboarding & Arm (24.5) & Hand (19.8) & Head (14.2) & Ankle (13.1) & Thigh (5.0) & {$[87,159]$} \\
\hline
\end{tabular}




\begin{tabular}{|c|c|c|c|c|c|c|}
\hline Skiing (Alpine) & Knee (32.2) & Head (11.0) & Ankle (7.6) & Leg (7.1) & Shoulder (6.5) & {$[13,160-167]$} \\
\hline Skiing (Nordic / Telemark) & Knee (25.0) & Hand (13.4) & Shoulder (11.8) & Ankle (10.4) & Head (6.2) & {$[164,168,169]$} \\
\hline Snowboarding / Snowblading & Hand (17.9) & Ankle (15.6) & Knee (13.9) & Head (11.0) & Shoulder (8.9) & {$[160,162,163,170-172]$} \\
\hline Soccer & Ankle (21.2) & Knee (16.3) & Thigh (12.2) & Leg (9.0) & Hip (4.3) & {$[23,25,34,51,52,58,64,77-79,87,111,113,173-197]$} \\
\hline Soccer (Indoor) & Ankle (23.7) & Knee (22.0) & Head (13.2) & Leg (7.4) & Foot (6.3) & {$[198,199]$} \\
\hline Softball & Ankle (18.3) & Knee (11.1) & Hand (6.6) & Leg (4.4) & Head (2.2) & {$[28,29,200]$} \\
\hline Speed Skating & Knee (23.4) & Ankle (14.0) & Trunk (13.5) & Leg (12.6) & Hip (11.0) & [201] \\
\hline Squash & Knee (20.8) & Trunk (15.9) & Ankle (12.6) & Shoulder (7.1) & $\operatorname{Leg}(2.5)$ & {$[31,73]$} \\
\hline Swimming & Leg (34.9) & Foot (34.9) & Ankle (8.8) & Shoulder (6.9) & Hand (5.9) & {$[77,93]$} \\
\hline Taekwondo & Leg (35.0) & Trunk (11.0) & Head (10.0) & Shoulder (10.0) & Ankle (8.0) & [202] \\
\hline Tennis & Trunk (16.1) & Shoulder (11.0) & Thigh (8.6) & Ankle (8.0) & Foot (7.0) & {$[73,203,204]$} \\
\hline Touch & Ankle (22.6) & Leg (16.4) & Knee (14.7) & Trunk (13.0) & Thigh (8.5) & [205] \\
\hline Track and Field (General) & Knee (21.8) & Leg (18.4) & Foot (13.0) & Ankle (11.2) & Hand (9.9) & {$[59,77,156]$} \\
\hline Track and Field (Track) & Leg (28.1) & Thigh (18.9) & Trunk (18.7) & Ankle (9.4) & Foot (9.4) & [156] \\
\hline Track and Field (Fields) & Ankle (39.2) & Thigh (26.1) & Trunk (17.4) & Knee (17.4) & Leg (8.7) & {$[156]$} \\
\hline Trampoline & Arm (48.1) & Head (6.3) & Ankle (6.2) & Leg (5.3) & & {$[206,207]$} \\
\hline Triathlon & Knee (22.5) & Trunk (11.8) & Foot (8.7) & Shoulder (8.2) & Ankle (7.8) & {$[93,208,209]$} \\
\hline Tug of War & Trunk (42.0) & Knee (17.0) & $\operatorname{Arm}(12.0)$ & Shoulder (11.0) & Ankle (3.5) & [210] \\
\hline Ultimate & Thigh (21.2) & Knee (15.1) & Ankle (12.2) & Leg (6.2) & Foot (6.2) & [211] \\
\hline Ultramarathon & Ankle (30.9) & Knee (27.0) & Leg (13.0) & Thigh (11.0) & Foot (4.0) & {$[212,213]$} \\
\hline Volleyball (Indoor) & Ankle (45.6) & Arm (15.4) & Knee (11.4) & Shoulder (4.8) & Hand (4.3) & {$[24,53,78,79,111,214-217]$} \\
\hline Volleyball (Beach) & Knee (18.6) & Trunk (16.4) & Shoulder (14.6) & Ankle (12.4) & Hand (8.0) & {$[54,215,218]$} \\
\hline
\end{tabular}




\begin{tabular}{|c|c|c|c|c|c|c|}
\hline Wakeboarding & Head (57.2) & Trunk (14.4) & Ankle (8.2) & Foot (6.4) & Knee (5.3) & [219] \\
\hline Wall Climbing & Ankle (60.0) & Shoulder (10.9) & Arm (7.3) & Hand (5.5) & Trunk (5.5) & {$[220]$} \\
\hline Water Skiing & Trunk (27.0) & Head (25.1) & Arm (13.0) & Knee (10.5) & Thigh (8.7) & [219] \\
\hline Windsurfing & Foot (17.7) & Knee (9.4) & Trunk (8.9) & Ankle (8.6) & Head (7.4) & [221] \\
\hline Wrestling & Knee (21.0) & Shoulder (13.9) & Head (11.0) & Ankle (9.0) & & {$[79,222]$} \\
\hline
\end{tabular}

* Items with weight prevalence percentage smaller than $1.0 \%$ are omitted. 
Table 4 - Most common ankle injury types in different sports and countries

\begin{tabular}{|c|c|c|c|c|c|}
\hline Sport & Most common ankle & ury types & & & References \\
\hline Aeroball & Sprain (90.0) & Fracture (10.0) & & & [61] \\
\hline American Football & Sprain (94.4) & Fracture (1.3) & & & {$[50,63,68]$} \\
\hline Australian Football & Sprain (100.0) & & & & [72] \\
\hline Badminton & Sprain (86.5) & Fracture (8.6) & Strain (5.4) & & {$[74,75]$} \\
\hline Basketball & Sprain (91.0) & Fracture (2.1) & Abrasion (0.7) & & {$[23,77,80,84,86,88,223]$} \\
\hline Cheerleading & Sprain (88.0) & & & & [91] \\
\hline Cycling & Abrasion (45.5) & Contusion (36.4) & Sprain (9.1) & Cramp (9.0) & [77] \\
\hline Dancing & Sprain (50.5) & Fracture (5.6) & & & {$[49,96]$} \\
\hline Field Hockey & Sprain (100.0) & & & & [38] \\
\hline Figure Skating & Sprain (77.0) & Fracture (23.5) & & & [102] \\
\hline Flag Football & Sprain (88.9) & Strain (11.1) & & & [103] \\
\hline Gynmastics & Impingement (55.6) & Sprain (44.4) & & & [112] \\
\hline Handball & Sprain (100.0) & & & & {$[23,39]$} \\
\hline Ice Hockey & Sprain (87.7) & Fracture (8.3) & & & {$[118,119,121]$} \\
\hline Kitesurfing & Sprain (77.8) & Fracture (22.2) & & & [123] \\
\hline Lacrosse & Sprain (87.5) & & & & [124] \\
\hline Luging & Sprain (35.0) & Fracture (22.2) & & & [125] \\
\hline Martial Arts & Sprain (91.7) & Fracture (8.3) & & & [127] \\
\hline Motorcycling & Sprain (31.3) & & & & [128] \\
\hline Mountaineering & Fracture (65.0) & Sprain (35.0) & & & [22] \\
\hline Netball & Sprain (85.9) & Fracture (7.9) & & & {$[130,131]$} \\
\hline
\end{tabular}




\begin{tabular}{|c|c|c|c|c|c|c|}
\hline Orienteering & Sprain (100.0) & & & & & {$[32,134,135]$} \\
\hline Parachuting & Fracture (100.0) & & & & & [138] \\
\hline Roller Skating & Fracture (86.5) & Sprain (13.5) & & & & {$[142,143]$} \\
\hline Rollerblading / Inline Skating & Fracture (83.3) & Sprain (16.7) & & & & [147] \\
\hline Rugby & Sprain (74.9) & & & & & {$[37,68,152,153]$} \\
\hline Scooter & Sprain (100.0) & & & & & [33] \\
\hline Skiing & Sprain (76.9) & Fracture (11.0) & & & & {$[13,165]$} \\
\hline Skiing (Nordic / Telemark) & Sprain (69.0) & Fracture (31.0) & & & & [169] \\
\hline Snowboarding & Sprain (53.6) & Fracture (42.5) & & & & {$[170,172,224]$} \\
\hline Soccer & Sprain (76.8) & Bruise (2.8) & Tendinitis (2.2) & Fracture (1.1) & & {$[23,34,51,77,176,179,186,188,190,191,193-196,225,226]$} \\
\hline Soccer (Indoor) & Sprain (87.8) & & & & & {$[198,199]$} \\
\hline Softball & Fracture (74.6) & Sprain(25.1) & & & & {$[28,29,200]$} \\
\hline Speed Skating & Sprain (50.0) & & & & & [201] \\
\hline Squash & Sprain (100.0) & & & & & [31] \\
\hline Swimming & Cramp (66.7) & Abrasion (33.3) & & & & {$[77]$} \\
\hline Tennis & Sprain (66.7) & & & & & [204] \\
\hline Track and Field (General) & Sprain (48.9) & Abrasion (17.0) & Cramp (17.0) & Strain (17.0) & & {$[59,77]$} \\
\hline Trampoline & Fracture (100.0) & & & & & [206] \\
\hline Ultimate & Sprain (89.9) & Bruise (3.4) & Strain (3.4) & Fracture (2.0) & Laceration (1.7) & [211] \\
\hline Volleyball (Indoor) & Sprain (99.3) & Fracture (0.7) & & & & {$[24,217]$} \\
\hline Wall Climbing & Fracture (57.6) & Sprain (42.4) & & & & [220] \\
\hline Windsurfing & Sprain (58.6) & Fracture (14.0) & & & & [221] \\
\hline
\end{tabular}

* Items with weight prevalence percentage smaller than $1.0 \%$ are omitted. 
Table 5 - Most common injured body sites in different countries

\begin{tabular}{|c|c|c|c|c|c|c|}
\hline Country & \multicolumn{5}{|c|}{ Most common injured body sites } & References \\
\hline Canada & Knee (20.9) & Ankle (14.0) & Head (10.0) & Trunk (8.5) & Leg (7.5) & [227] \\
\hline Finland & Knee (24.3) & Ankle (12.5) & Leg (9.0) & Trunk (6.8) & Shoulder (3.3) & [228-230] \\
\hline Holland & Hand (21.8) & Ankle (20.8) & Foot (13.4) & Knee (13.2) & Thigh (4.1) & {$[231,232]$} \\
\hline Hong Kong & Knee (27.0) & Ankle (11.2) & Foot (10.0) & Leg (10.0) & Hand (9.1) & [77, 78,233$]$ \\
\hline Saudi Arabia & Knee (27.0) & Ankle (12.0) & Arm (11.0) & Thigh (10.0) & Hand (10.0) & [234] \\
\hline Sweden & Hand (19.8) & Knee (16.0) & Ankle (15.6) & Foot (15.6) & Leg (6.6) & [1] \\
\hline United Kingdom & Knee (18.3) & Ankle (15.1) & Hand (8.6) & Thigh (6.2) & Trunk (6.2) & [235-239] \\
\hline United States & Knee (22.1) & Ankle (12.3) & $\operatorname{Leg}(7.0)$ & Shoulder (5.8) & Trunk (4.9) & $\begin{array}{l}{[8,240-244]} \\
\end{array}$ \\
\hline Sport / Country & \multicolumn{5}{|c|}{ Most common ankle injury types } & References \\
\hline Holland & Sprain (73.0) & Fracture (16.0) & Contusion (5.0) & & & [232] \\
\hline Hong Kong & Sprain (33.0) & Abrasion (25.2) & Cramp (17.4) & Contusion (13.0) & Strain (11.3) & [77] \\
\hline United States & Sprain (68.3) & Fracture (7.4) & & & & {$[12,40,80,240,241]$} \\
\hline
\end{tabular}


Table 6 - Ankle injury incidence rate in different sports (game incidence and training incidence in bracket)

\begin{tabular}{|c|c|c|c|c|}
\hline Sport & Ankle injury incidence rate & & & \\
\hline & per 1000 person-hours & per 1000 person-year & per 1000 person-season & per 1000 person-exposure \\
\hline Adventure Racing & (Game: $0.30^{[60]}$ ) & & & \\
\hline Aeroball & & $1.37^{[61]}$ & & \\
\hline American Football & $\begin{array}{l}0.54-4.15^{[55,62,65]}, \quad \text { (Game: } \\
\left.13.80^{[66]}\right)\end{array}$ & $26.30-72.00^{[50,63,67]}$ & & $0.71^{[245]}$, (Game: $1.23-6.38^{[56,68]}$ ) \\
\hline Australian Football & $\begin{array}{l}1.30-2.31^{[69,71]}, \quad \text { (Game: } \\
\left.3.91-4.86^{[36]}\right)\end{array}$ & & (Game: $111.10^{[72]}$ ) & \\
\hline Badminton & $0.68^{[75]}$ & & & \\
\hline Baseball & & & & $0.14^{[245]}$ \\
\hline Basketball & $1.00-5.20^{[23,81,83,85]}$ & $178.60^{[223]}$ & & $\begin{array}{l}0.47-9 \cdot 17^{[57,84,245,246]}, \quad \text { (Game: } \\
3.62-3 \cdot 77^{[82,88]} \text { ) }\end{array}$ \\
\hline Cheerleading & $0.28-0.33^{[26,90]}$ & & & $0.21-0.34^{[91,245]}$ \\
\hline Cricket & $1.21^{[92]}$ & & & \\
\hline Dancing & $0.32-2.66^{[12,96,98]}$ & $117.10-466.20^{[95,99]}$ & $131.40^{[15]}$ & \\
\hline Equestrian & & $0.04-10.30^{[100]}$ & & \\
\hline Field Hockey & & $1000.00^{[38]}$ & & \\
\hline Floorball & $0.87^{[30]}$ & & & \\
\hline Gaelic Football & & $374.70^{[105]}$ & & \\
\hline Golf & & & $20.60^{[107]}$ & \\
\hline Gymnastics & $\begin{array}{l}0.12-0.62^{[27,110]}, \quad \text { (Training: } \\
\left.1.03^{[109]}\right)\end{array}$ & $230.80-425.90^{[108,112]}$ & $40.80-46.70^{[14]}$ & \\
\hline
\end{tabular}




\begin{tabular}{|c|c|c|c|c|}
\hline Handball & $\begin{array}{l}0.38-1.59^{[23,39,114]}, \quad \text { (Game: } \\
\left.1.32^{[113]}\right)\end{array}$ & & & \\
\hline Hurling / Camogie & $32.88^{[116]}$ & & & \\
\hline Ice Hockey & $\begin{array}{l}0.12-0.20^{[118,119]} \text {, (Game: } 1.53^{[118]} \text {; } \\
\text { Training: } 0.18^{[118]} \text { ) }\end{array}$ & & & $0.46-0.71^{[117,121]}$ \\
\hline Jockey & & (Game: $64.81^{[122]}$ ) & & \\
\hline Kitesurfing & $2.0^{[123]}$ & & & \\
\hline Lacrosse & & & & $0.47-2.66^{[124]}$ \\
\hline Luging & & & & $0.45^{[125]}$ \\
\hline Motorcycle Racing & $\begin{array}{l}3.73^{[129]}, \quad \text { (Game: } 2.85-6.15^{[129]} \text {; } \\
\text { Training: } 0.00^{[129]} \text { ) }\end{array}$ & (Game: $4.50^{[128]}$ ) & & \\
\hline Netball & $3.27^{[132]}$ & & & $5.26^{[82]}$, (Game: $45.60^{[130]}$ ) \\
\hline Orienteering & $0.82^{[136]}$, (Game: $3.80^{[32]}$ ) & $571.43^{[137]}$ & & (Game: $1.03^{[135]}$ ) \\
\hline Parachuting & & $0.38^{[139]}$ & & $0.45^{[138]}$ \\
\hline Rodeo & & & & (Game: $0.75^{[141]}$ ) \\
\hline Rugby & $\begin{array}{l}0.23-8.14^{[152,153]}, \quad \text { (Game: } \\
5.77-14.00^{[150,155]} ; \\
\left.0.26^{[149]}\right)\end{array}$ & $233.40^{[37]}$ & & (Game: $2.72-8.88^{[68,151]}$ ) \\
\hline Running & $0.02^{[157]}$ & $62.50-111.00^{[156]}$ & & \\
\hline Skiing (Alpine) & & & & $0.13-3.18^{[13,164,165]}$ \\
\hline Skiing (Nordic / Telemark) & & & & $0.07^{[164]}$ \\
\hline Snowboarding / Snowblading & & & & $0.97^{[160]}$, (Game: $0.13^{[172]}$ ) \\
\hline Soccer & $0.17-6.52^{[23,51,174,177-181,183,185,187,192-}$ & $71.13^{[34]}$ & $10.99-1200.00^{[25,182,186,190,226]}$, & $0.55-0.76^{[245]}$ \\
\hline
\end{tabular}




\begin{tabular}{|c|c|c|c|c|}
\hline & $\begin{array}{lr}197] & \text { (Game: } \\
0.00-34.83^{[113,174,176,184,191]} \\
{[173,177,181,188,225]}\end{array}$ & & $\begin{array}{l}\text { (Game: } \quad 39.79-143.40^{[182,190]} \text {; } \\
\text { Training: } 36.35-64.00^{[182,190]} \text { ) }\end{array}$ & \\
\hline Soccer (Indoor) & (Game: $11.49-11.68^{[198,199]}$ ) & & & \\
\hline Softball & & $41.70^{[200]}$ & & $0.41^{[245]}$ \\
\hline Speed Skating & & $168.40^{[201]}$ & & \\
\hline Tennis & & & & $11.30^{[203]}$, (Game: $0.30^{[204]}$ ) \\
\hline Touch & $1.10^{[205]}$ & & & \\
\hline Track and Field (General) & & $29.90-102.00^{[59,156]}$ & & $0.13-0.14^{[245]}$ \\
\hline Track and Field (Track) & & $0.00-111.00^{[156]}$ & & \\
\hline Track and Field (Fields) & & $158.00-286.00^{[156]}$ & & \\
\hline Trampoline & & $0.02-0.05^{[206]}$ & & \\
\hline Triathlon & $1.49-4.70^{[208]}$ & & & \\
\hline Ultimate & & (Game: $14.75^{[211]}$ ) & & \\
\hline Volleyball (Indoor) & $\begin{array}{l}0.60-2.01^{[24,214,215,217]}, \quad \text { (Game: } \\
\left.5.50^{[216]}\right)\end{array}$ & & & $0.68^{[245]}$ \\
\hline Volleyball (Beach) & $\begin{array}{ll}0.20^{[215]}, \quad \text { (Game: } & 0.57^{[218]} ; \\
\left.\text { Training: } 0.13^{[218]}\right)\end{array}$ & & & \\
\hline Wall Climbing & & & & $0.02^{[220]}$ \\
\hline Windsurfing & & & & $0.09^{[221]}$ \\
\hline Wrestling & & & & $\begin{array}{l}0.09-0.86^{[245,247]}, \text { (Game: } 2.71^{[247]} \text {; } \\
\text { Training: } 0.63^{[247]} \text { ) }\end{array}$ \\
\hline
\end{tabular}



Table 7 - Ankle sprain incidence rate in different sports (game incidence and training incidence in bracket)

\begin{tabular}{|c|c|c|c|c|}
\hline \multirow[b]{2}{*}{ Sport } & \multicolumn{4}{|l|}{ Ankle sprain incidence rate } \\
\hline & per 1000 person-hours & per 1000 person-year & per 1000 person-season & per 1000 person-exposure \\
\hline Aeroball & & $1.23^{[61]}$ & & \\
\hline American Football & & $59.40-60.60^{[50,63]}$ & & (Game: $6.06^{[68]}$ ) \\
\hline Australian Football & (Game: $3.69-4.86^{[36,248]}$ ) & & (Game: $111.10^{[72]}$ ) & \\
\hline Badminton & $0.53^{[75]}$ & & & \\
\hline Basketball & $1.00^{[23]}$ & $173.50^{[223]}$ & & $0.42-1.90^{[84,249]}$, (Game: $3.45^{[88]}$ ) \\
\hline Cheerleading & & & & $0.18^{[91]}$ \\
\hline \multicolumn{5}{|l|}{ Cricket } \\
\hline Dancing & $0.08-0.30^{[96,98]}$ & $155.40^{[99]}$ & & \\
\hline Field Hockey & & $1000.00^{[38]}$ & & $0.90^{[249]}$ \\
\hline \multicolumn{5}{|l|}{ Floorball } \\
\hline Gymnastics & & $102.60^{[112]}$ & & \\
\hline Handball & $0.38-1.59^{[23,39]}$ & & & \\
\hline Ice Hockey & $0.05-0.12^{[118,119]}$ & & & $0.35-0.62^{[117,121]}$ \\
\hline Kitesurfing & $0.4^{[123]}$ & & & \\
\hline Lacrosse & & & & $0.39-2.56^{[124,249]}$ \\
\hline Luging & & & & $0.16^{[125]}$ \\
\hline Motorcycle Racing & & (Game: $1.40^{[128]}$ ) & & \\
\hline Netball & & & & (Game: $40.06^{[130]}$ ) \\
\hline Orienteering & & & & (Game: $1.03^{[135]}$ ) \\
\hline
\end{tabular}




\begin{tabular}{|c|c|c|c|c|}
\hline Parachuting & & & & $0.00^{[138]}$ \\
\hline Rugby & $0.15-4.20^{[152,153]}$ & $233.40^{[37]}$ & & (Game: $6.31^{[68]}$ ) \\
\hline Skiing (Alpine) & & & & $0.36-1.60^{[13,165]}$ \\
\hline Snowboarding / Snowblading & & & & (Game: $0.13^{[172]}$ ) \\
\hline Soccer & $\begin{array}{l}0.15-2.52^{[23,51,174,178,179,181,193-196,250]} \\
\text { (Game: } \\
0.34-4.59^{[174,188,191,225,251]} \\
\text { Training: } 0.21^{[174]} \text { ) }\end{array}$ & $71.13^{[34]}$ & $54.79-1200.00^{[186,190,226]}$ & $0.73-1.15^{[249]}$ \\
\hline Soccer (Indoor) & (Game: 9.65-11.68 ${ }^{[198,199]}$ ) & & & \\
\hline Softball & & $41.7^{[200]}$ & & \\
\hline Speed Skating & & $84.20^{[201]}$ & & \\
\hline Tennis & & & & (Game: $0.20^{[204]}$ ) \\
\hline Track and Field (General) & & $29.90^{[59]}$ & & \\
\hline Trampoline & & $0.00^{[206]}$ & & \\
\hline Ultimate & & (Game: $13.30^{[211]}$ ) & & \\
\hline Volleyball (Indoor) & $1.37-1.99^{[24,217]}$ & & & \\
\hline \multicolumn{5}{|l|}{ Volleyball (Beach) } \\
\hline Wall Climbing & & & & $0.01^{[220]}$ \\
\hline Windsurfing & & & & $0.05^{[221]}$ \\
\hline
\end{tabular}




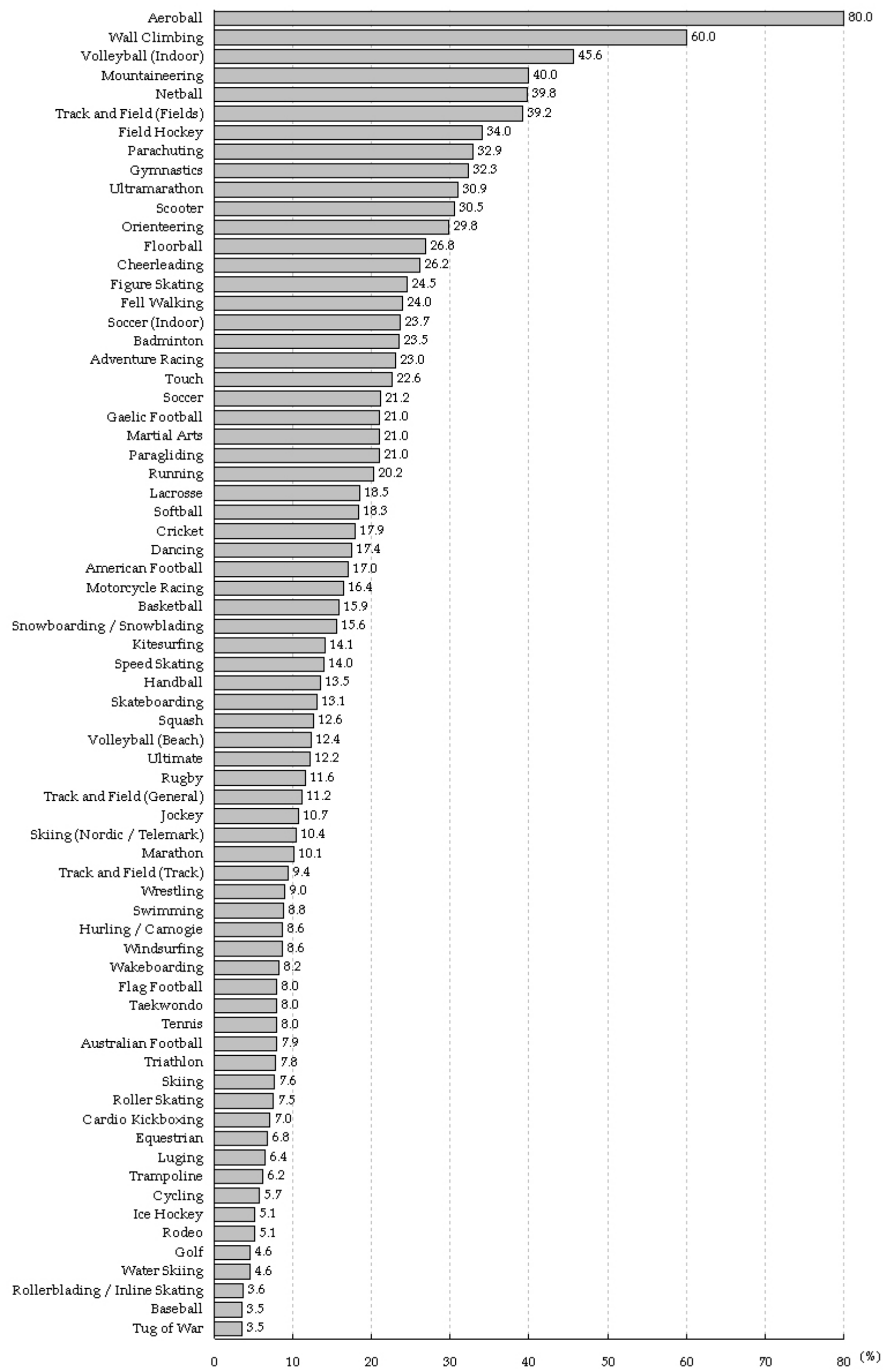

Figure 1 - Weighted percentage of ankle injury in the 70 included sports 


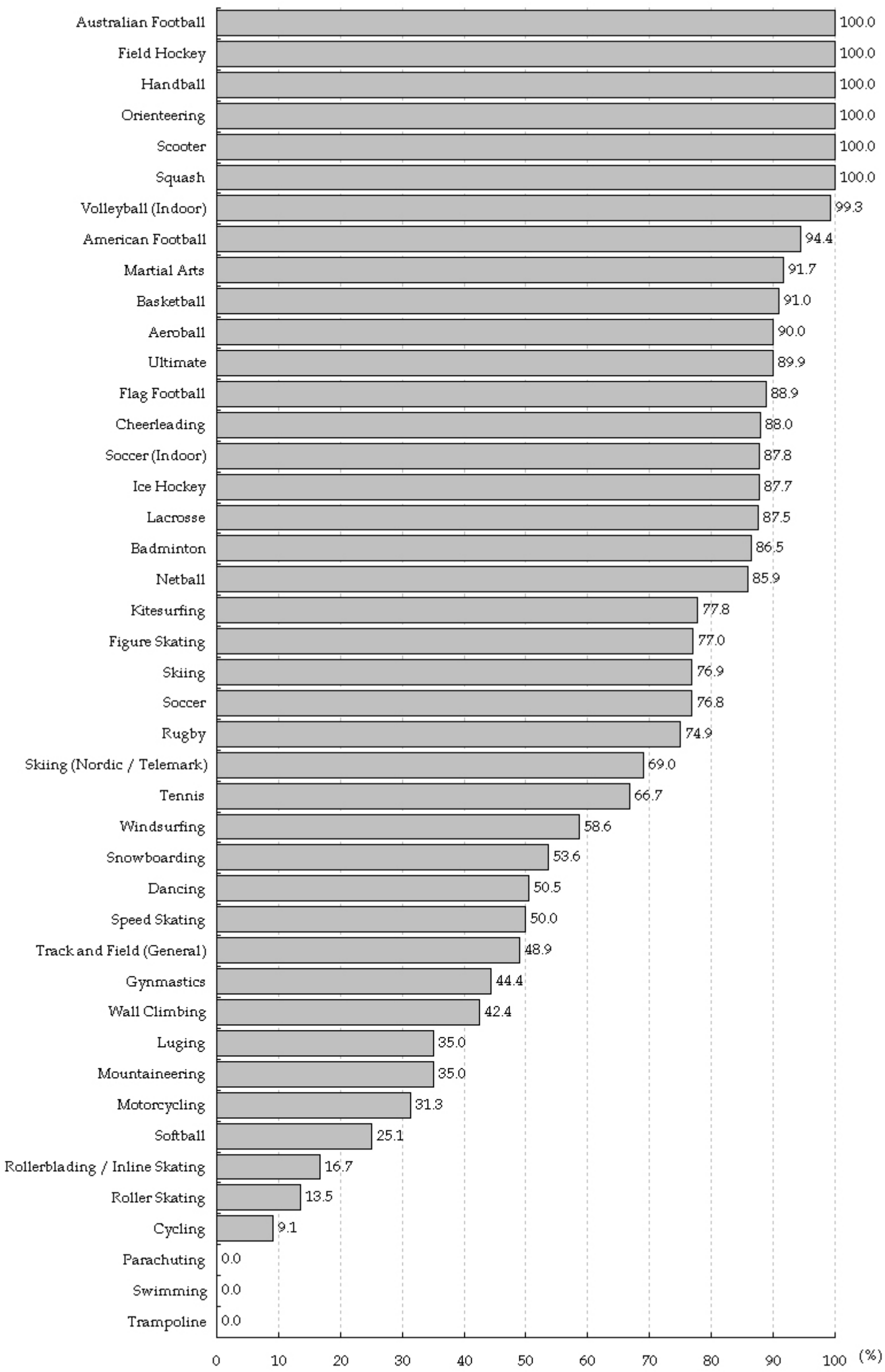

Figure 2 - Weighted percentage of ankle sprains in the 43 included sports 